4

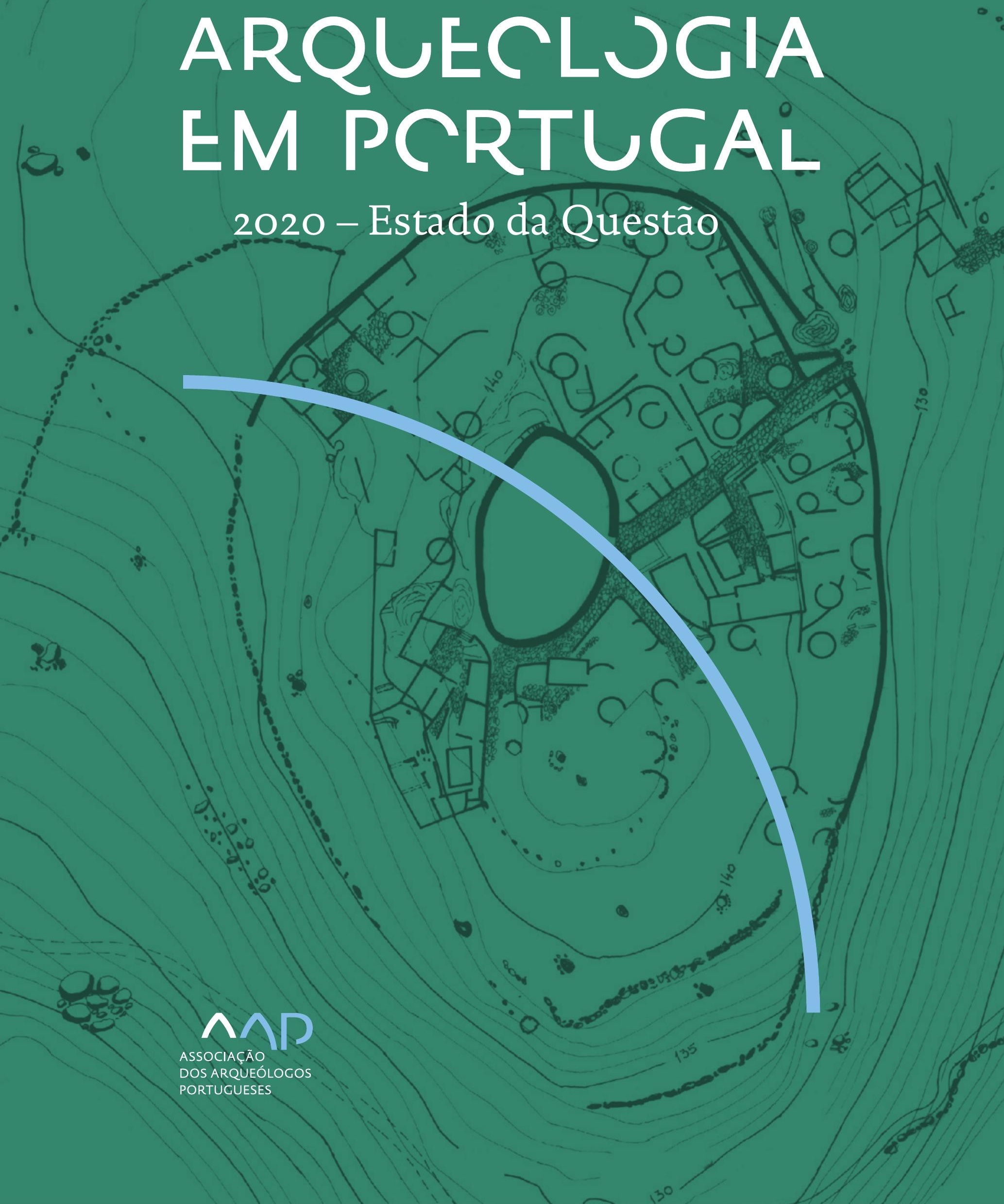


Coordenação editorial: José Morais Arnaud, César Neves e Andrea Martins Design gráfico: Flatland Design

AAP - ISBN: 978-972-9451-89-8

CITCEM - ISBN: 978-989-8970-25-1

Associação dos Arqueólogos Portugueses e CITCEM

Lisboa, 2020

O conteúdo dos artigos é da inteira responsabilidade dos autores. Sendo assim a Associação dos Arqueólogos Portugueses declina qualquer responsabilidade por eventuais equívocos ou questões de ordem ética e legal.

Desenho de capa:

Planta do castro de Monte Mozinho (Museu Municipal de Penafiel).

\section{$\hat{\wedge} \mathrm{P}$}

DOS ARQUEÓLOGOS PORTUGUESES

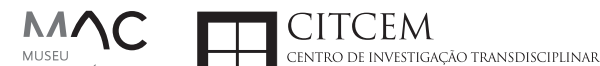
MUSEU
ARQUELLÓGICO
DO CARMO
U.PORTO

FLUP FACULDADE DE LETRAS
UNIVERSIDADE DO PORTO

Apoio

EC para a Ciência 


\section{Índice}

15 Prefácio

José Morais Arnaud

\section{Historiografia e Teoria}

17 Território, comunidade, memória e emoção: a contribuição da história da arqueologia (algumas primeiras e breves reflexões)

Ana Cristina Martins

25 Como descolonizar a arqueologia portuguesa?

Rui Gomes Coelho

41 Arqueologia e Modernidade: uma revisitação pessoal e breve de alguns aspetos da obra homónima de Julian Thomas de 2004

Vítor Oliveira Jorge

57 Dados para a História das Mulheres na Arqueologia portuguesa, dos finais do século XIX aos inícios do século XX: números, nomes e tabelas

Filipa Dimas / Mariana Diniz

73 Retractos da arqueologia portuguesa na imprensa: (in)visibilidades no feminino

Catarina Costeira / Elsa Luís

85 Arqueologia e Arqueólogos no Norte de Portugal Jacinta Bugalhão

101 Vieira Guimarães (1864-1939) e a arqueologia em Tomar: uma abordagem sobre o território e as gentes

João Amendoeira Peixoto / Ana Cristina Martins

115 Os memoráveis? A arqueologia algarvia na imprensa nacional e regional na presente centúria (2001-2019): características, visões do(s) passado(s) e a arqueologia

enquanto marca

Frederico Agosto / João Silva

129 A Evolução da Arqueologia Urbana e a Valorização Patrimonial no Barlavento Algarvio: Os casos de Portimão e Silves

Artur Mateus / Diogo Varandas / Rafael Boavida

\section{Gestão, Valorização e Salvaguarda do Património}

145 O Caderno Reivindicativo e as condições de trabalho em Arqueologia Miguel Rocha / Liliana Matias Carvalho / Regis Barbosa / Mauro Correia / Sara Simões / Jacinta Bugalhão / Sara Brito / Liliana Veríssimo Carvalho / Richard Peace / Pedro Peça / Cézer Santos

155 Os Estudos de Impacte Patrimonial como elemento para uma estratégia sustentável de minimização de impactes no âmbito de reconversões agrícolas Tiago do Pereiro

165 Salvaguarda de Património arqueológico em operações florestais: gestão e sensibilização Filipa Bragança / Gertrudes Zambujo / Sandra Lourenço / Belém Paiva / Carlos Banha / Frederico Tatá Regala / Helena Moura / Jacinta Bugalhão / João Marques / José Correia / Pedro Faria / Samuel Melro

179 Os valores do Património: uma investigação sobre os Sítios Pré-históricos de Arte Rupestre do Vale do Rio Côa e de Siega Verde José Paulo Francisco 
189 Conjugando recursos arqueológicos e naturais para potenciar as visitas ao Geoparque Litoral de Viana do Castelo (Noroeste de Portugal)

Hugo A. Sampaio / Ana M.S. Bettencourt / Susana Marinho / Ricardo Carvalhido

203 Áreas de Potencial Arqueológico na Região do Médio Tejo: Modelo Espacial Preditivo Rita Ferreira Anastácio / Ana Filipa Martins / Luiz Oosterbeek

223 Património Arqueológico e Gestão Territorial: O contributo da Arqueologia para a revisão do PDM de Avis

Ana Cristina Ribeiro

237 A coleção arqueológica do extinto Museu Municipal do Porto - Origens, Percursos e Estudos

Sónia Couto

251 Valpaços - uma nova carta arqueológica

Pedro Pereira / Maria de Fátima Casares Machado

263 Arqueologia na Cidade de Peniche

Adriano Constantino / Luís Rendeiro

273 Arqueologia Urbana: a cidade de Lagos como caso de Estudo Cátia Neto

285 Estratégias de promoção do património cultural subaquático nos Açores. O caso da ilha do Faial

José Luís Neto / José Bettencourt / Luís Borges / Pedro Parreira

297 Carta Arqueológica da Cidade Velha: Uma primeira abordagem

Jaylson Monteiro / Nireide Tavares / Sara da Veiga / Claudino Ramos / Edson Brito /

Carlos Carvalho / Francisco Moreira / Adalberto Tavares

311 Antropologia Virtual: novas metodologias para a análise morfológica e funcional Ricardo Miguel Godinho / Célia Gonçalves

\section{Didáctica da Arqueologia}

327 Como os projetos de Arqueologia podem contribuir para uma comunidade culturalmente mais consciente Alexandra Figueiredo / Claúdio Monteiro / Adolfo Silveira / Ricardo Lopes

337 Educação Patrimonial - Um cidadão esclarecido é um cidadão ativo! Ana Paula Almeida

351 A aproximação da Arqueologia à sala de aula: um caso de estudo no $3^{\circ}$ ciclo do Ensino Básico Luís Serrão Gil

363 Arqueologia 3.o - Pensar e comunicar a Arqueologia para um futuro sustentável Mónica Rolo

377 “Conversa de Arqueólogos" - Divulgar a Arqueologia em tempos de Pandemia Diogo Teixeira Dias

389 Escola Profissional de Arqueologia: desafios e oportunidades Susana Nunes / Dulcineia Pinto / Júlia Silva / Ana Mascarenhas

399 Os Museus de Arqueologia e os Jovens: a oferta educativa para o público adolescente Beatriz Correia Barata / Leonor Medeiros

411 O museu universitário como mediador entre a ciência e a sociedade: o exemplo da secção de arqueologia no Museu de História Natural e da Ciência da Universidade do Porto (MHNC-UP)

Rita Gaspar 
421 Museu de Lanifícios: Real Fábrica de Panos. Atividades no âmbito da Arqueologia Beatriz Correia Barata / Rita Salvado

427 Arqueologia Pública e o caso da localidade da Mata (Torres Novas) Cláudia Manso / Ana Rita Ferreira / Cristiana Ferreira / Vanessa Cardoso Antunes

431 Do sítio arqueológico ao museu: um percurso (também) didático Lídia Fernandes

447 Estão todos convidados para a Festa! E para dançar também... O projecto do Serviço Educativo do Museu Arqueológico do Carmo na $5^{\underline{a}}$ Edição da Festa da Arqueologia Rita Pires dos Santos

459 O “Clã de Carenque”, um projeto didático de arqueologia Eduardo Gonzalez Rocha

469 Mediação cultural: peixe que puxa carroça nas Ruínas Romanas de Troia Inês Vaz Pinto / Ana Patrícia Magalhães / Patrícia Brum / Filipa Santos

481 Didática Arqueológica, experiências do Projeto Mértola Vila Museu Maria de Fátima Palma / Clara Rodrigues / Susana Gómez / Lígia Rafael

\section{Arte Rupestre}

497 Os inventários de arte rupestre em Portugal Mila Simões de Abreu

513 O projeto FIRST-ART - conservação, documentação e gestão das primeiras manifestações de arte rupestre no Sudoeste da Península Ibérica: as grutas do Escoural e Maltravieso Sara Garcês / Hipólito Collado / José Julio García Arranz / Luiz Oosterbeek / António Carlos Silva / Pierluigi Rosina / Hugo Gomes / Anabela Borralheiro Pereira / George Nash / Esmeralda Gomes / Nelson Almeida / Carlos Carpetudo

523 Trabalhos de documentação de arte paleolítica realizados no âmbito do projeto PalæoCôa André Tomás Santos / António Fernando Barbosa / Luís Luís / Marcelo Silvestre / Thierry Aubry

537 Imagens fantasmagóricas, silhuetas elusivas: as figuras humanas na arte do Paleolítico Superior da região do Côa Mário Reis

$55^{1}$ Os motivos zoomórficos representados nas placas de tear de Vila Nova de São Pedro (Azambuja, Portugal) Andrea Martins / César Neves / José M. Arnaud / Mariana Diniz

571 Arte Rupestre do Monte de Góios (Lanhelas, Caminha). Síntese dos resultados dos trabalhos efectuados em 2007-2009 Mário Varela Gomes

599 Gravuras rupestres de barquiformes no Monte de S. Romão, Guimarães, Noroeste de Portugal Daniela Cardoso

613 Círculos segmentados gravados na Bacia do Rio Lima (Noroeste de Portugal): contributos para o seu estudo Diogo Marinho / Ana M.S. Bettencourt / Hugo Aluai Sampaio

631 Equídeos gravados no curso inferior do Rio Mouro, Monção (NW Portugal). Análise preliminar Coutinho, L.M. / Bettencourt, A.M.S / Sampaio, Hugo A.S

645 Paletas na Arte Rupestre do Noroeste de Portugal. Inventário preliminar Bruna Sousa Afonso / Ana M. S. Bettencourt / Hugo A. Sampaio 


\section{Pré-História}

661 O projeto Miño/Minho: balanço de quatro anos de trabalhos arqueológicos Sérgio Monteiro-Rodrigues / João Pedro Cunha-Ribeiro / Eduardo Méndez-Quintas / Carlos Ferreira / Pedro Xavier / José Meireles / Alberto Gomes / Manuel Santonja / Alfredo Pérez-González

677 A ocupação paleolítica da margem esquerda do Baixo Minho: a indústria lítica do sítio de Pedreiras 2 (Monção, Portugal) e a sua integração no contexto regional Carlos Ferreira / João Pedro Cunha-Ribeiro / Sérgio Monteiro-Rodrigues / Eduardo Méndez-Quintas / Pedro Xavier / José Meireles / Alberto Gomes / Manuel Santonja / Alfredo Pérez-González

693 O sítio acheulense do Plistocénico médio da Gruta da Aroeira Joan Daura / Montserrat Sanz / Filipa Rodrigues / Pedro Souto / João Zilhão

703 As sociedades neandertais no Barlavento algarvio: modelos preditivos com recurso aos SIG

Daniela Maio

715 A utilização de quartzo durante o Paleolítico Superior no território dos vales dos rios Vouga e Côa

Cristina Gameiro / Thierry Aubry / Bárbara Costa / Sérgio Gomes / Luís Luís / Carmen Manzano / André Tomás Santos

733 Uma perspetiva diacrónica da ocupação do concheiro do Cabeço da Amoreira (Muge, Portugal) a partir da tecnologia lítica Joana Belmiro / João Cascalheira / Célia Gonçalves

745 Novos dados sobre a Pré-história Antiga no concelho de Palmela. A intervenção arqueológica no sítio do Poceirão I

Michelle Teixeira Santos

757 Problemas em torno de Datas Absolutas Pré-Históricas no Norte do Alentejo Jorge de Oliveira

771 Povoamento pré-histórico nas áreas montanhosas do NO de Portugal: o Abrigo 1 de Vale de Cerdeira Pedro Xavier / José Meireles / Carlos Alves

783 Apreciação do povoamento do Neolítico Inicial na Baixa Bacia do Douro. A Lavra I (Serra da Aboboreira) como caso de estudo Maria de Jesus Sanches

797 O Processo de Neolitização na Plataforma do Mondego: os dados do Sector C do Outeiro dos Castelos de Beijós (Carregal do Sal)

João Carlos de Senna-Martinez / José Manuel Quintã Ventura / Andreia Carvalho / Cíntia Maurício

823 Novos trabalhos na Lapa da Bugalheira (Almonda, Torres Novas) Filipa Rodrigues / Pedro Souto / Artur Ferreira / Alexandre Varanda / Luís Gomes / Helena Gomes / João Zilhão

837 A pedra polida e afeiçoada do sítio do Neolítico médio da Moita do Ourives (Benavente, Portugal)

César Neves

857 Casal do Outeiro (Encarnação, Mafra): novos contributos para o conhecimento do povoamento do Neolítico final na Península de Lisboa.

Cátia Delicado / Carlos Maneira e Costa / Marta Miranda / Ana Catarina Sousa

873 Stresse infantil, morbilidade e mortalidade no sítio arqueológico do Neolítico Final/ Calcolítico ( $4^{\circ}$ e $3^{\circ}$ milénio a.C.) do Monte do Carrascal 2 (Ferreira do Alentejo, Beja) Liliana Matias de Carvalho / Sofia N. Wasterlain 
885 Come together: O Conjunto Megalítico das Motas (Monção, Viana do Castelo) e as expressões Campaniformes do Alto Minho Ana Catarina Basílio / Rui Ramos

899 Trabalhos arqueológicos no sítio Calcolítico da Pedreira do Poio Carla Magalhães / João Muralha / Mário Reis / António Batarda Fernandes

913 O sítio arqueológico de Castanheiro do Vento. Da arquitectura do sítio à arquitectura de um território João Muralha Cardoso

925 Estudo zooarqueológico das faunas do Calcolítico final de Vila Nova de São Pedro (Azambuja, Portugal): Campanhas de 2017 e 2018 Cleia Detry / Ana Catarina Francisco / Mariana Diniz / Andrea Martins / César Neves / José Morais Arnaud

943 As faunas depositadas no Museu Arqueológico do Carmo provenientes de Vila Nova de São Pedro (Azambuja): as campanhas de 1937 a 1967 Ana Catarina Francisco / Cleia Detry / César Neves / Andrea Martins / Mariana Diniz / José Morais Arnaud

959 Análise funcional de material lítico em sílex do castro de Vila Nova de S. Pedro (Azambuja, Portugal): uma primeira abordagem Rafael Lima

971 O recinto da Folha do Ouro 1 (Serpa) no contexto dos recintos de fossos calcolíticos alentejanos

António Carlos Valera / Tiago do Pereiro / Pedro Valério / António M. Monge Soares

\section{Proto-História}

987 Produção de sal marinho na Idade do Bronze do noroeste Português. Alguns dados para uma reflexão

Ana M. S. Bettencourt / Sara Luz / Nuno Oliveira / Pedro P. Simões / Maria Isabel C. Alves / Emílio Abad-Vidal

1001 A estátua-menir do Pedrão ou de São Bartolomeu do Mar (Esposende, noroeste de Portugal) no contexto arqueológico da fachada costeira de entre os rios Neiva e Cávado Ana M. S. Bettencourt / Manuel Santos-Estévez / Pedro Pimenta Simões / Luís Gonçalves

1015 O Castro do Muro (Vandoma/Baltar, Paredes) - notas para uma biografia de ocupação da Idade do Bronze à Idade Média

Maria Antónia D. Silva / Ana M. S. Bettencourt / António Manuel S. P. Silva / Natália Félix

1031 Do Bronze Final à Idade Média - continuidades e hiatos na ocupação de Povoados em Oliveira de Azeméis João Tiago Tavares / Adriaan de Man

1041 As faunas do final da Idade do Bronze no Sul de Portugal: leituras desde o Outeiro do Circo (Beja)

Nelson J. Almeida / Íris Dias / Cleia Detry / Eduardo Porfírio / Miguel Serra

1055 A Espada do Monte das Oliveiras (Serpa) - uma arma do Bronze Pleno do Sudoeste Rui M. G. Monge Soares / Pedro Valério / Mariana Nabais / António M. Monge Soares

1065 São Julião da Branca (Albergaria-a-Velha) - Investigação e valorização de um povoado do Bronze Final

António Manuel S. P. Silva / Paulo A. P. Lemos / Sara Almeida e Silva / Edite Martins de Sá

1083 Do castro de S. João ao Mosteiro de Santa Clara: notícia de uma intervenção arqueológica, em Vila do Conde Rui Pinheiro 
1095 O castro de Ovil (Espinho), um quarto de século de investigação - resultados e questões em aberto

Jorge Fernando Salvador / António Manuel S. P. Silva

1111 O Castro de Salreu (Estarreja), um povoado proto-histórico no litoral do Entre Douro e Vouga

Sara Almeida e Silva / António Manuel S. P. Silva / Paulo A. P. Lemos / Edite Martins de Sá

1127 Castro de Nossa Senhora das Necessidades (Sernancelhe): uma primeira análise artefactual Telma Susana O. Ribeiro

${ }_{1141}$ A cividade de Bagunte. O estado atual da investigação Pedro Brochado de Almeida

1153 Zoomorfos na cerâmica da Idade do Ferro no NW Peninsular: inventário, cronologias e significado Nuno Oliveira / Cristina Seoane

1163 Vasos gregos em Portugal: diferentes maneiras de contar a história do intercâmbio cultural na Idade do Ferro

Daniela Ferreira

1175 Os exotica da necrópole da Idade do Ferro do Olival do Senhor dos Mártires (Alcácer do Sal) no seu contexto regional

Francisco B. Gomes

\section{Antiguidade Clássica e Tardia}

1191 O uso de madeira como combustível no sítio da Quinta de Crestelos (Baixo Sabor): da Idade do Ferro à Romanização Filipe Vaz / João Tereso / Sérgio Simões Pereira / José Sastre / Javier Larrazabal Galarza / Susana Cosme / José António Pereira / Israel Espi

1207 Cultivos de Época Romana no Baixo Sabor: continuidade em tempos de mudança? João Pedro Tereso / Sérgio Simões Pereira / Filipe Santos / Luís Seabra / Filipe Vaz

1221 A casa romana na Hispânia: aplicação dos modelos itálicos nas províncias ibéricas Fernanda Magalhães / Diego Machado / Manuela Martins

1235 As pinturas murais romanas da Rua General Sousa Machado, n. ${ }^{5}$ 1, Chaves José Carvalho

1243 Trás do Castelo (Vale de Mir, Pegarinhos, Alijó) - Uma exploração agrícola romana do Douro

Tony Silvino / Pedro Pereira

1255 A sequência de ocupação no quadrante sudeste de Bracara Augusta: as transformações de uma unidade doméstica Lara Fernandes / Manuela Martins

1263 Os Mosaicos com decoração geométrica e geométrico-vegetalista dos sítios arqueológicos da área do Conuentus Bracaraugustanus. Novas abordagens quanto à conservação, restauro, decoração e datação Maria de Fátima Abraços / Licínia Wrench

1277 “Casa Romana” do Castro de São Domingos (Cristelos, Lousada): Escavação, Estudo e Musealização Paulo André de P. Lemos

1291 A arqueobotânica no Castro de Guifões (Matosinhos, Noroeste de Portugal): O primeiro estudo carpológico

Luís Seabra / Andreia Arezes / Catarina Magalhães / José Varela / João Pedro Tereso 
1305 Um Horreum Augustano na Foz do Douro (Monte do Castelo de Gaia, Vila Nova de Gaia) Rui Ramos

1311 Ponderais romanos na Lusitânia: padrões, formas, materiais e contextos de utilização Diego Barrios Rodríguez

1323 Um almofariz centro-itálico na foz do Mondego

Marco Penajoia

1335 Estruturas romanas de Carnide - Lisboa Luísa Batalha / Mário Monteiro / Guilherme Cardoso

1347 O contexto funerário do sector da "necrópole NO" da Rua das Portas de S. Antão (Lisboa): o espaço, os artefactos, os indivíduos e a sua interconectividade na interpretação do passado Sílvia Loja, José Carlos Quaresma, Nelson Cabaço, Marina Lourenço, Sílvia Casimiro, Rodrigo Banha da Silva, Francisca Alves-Cardoso

${ }_{1361}$ Povoamento em época Romana na Amadora - resultados de um projeto pluridisciplinar Gisela Encarnação / Vanessa Dias

1371 A Arquitectura Residencial em Mirobriga (Santiago do Cacém): contributo a partir de um estudo de caso Filipe Sousa / Catarina Felício

${ }_{1385}$ O fim do ciclo. Saneamento e gestão de resíduos nos edifícios termais de Mirobriga (Santiago do Cacém)

Catarina Felício / Filipe Sousa

1399 Balsa, Topografia e Urbanismo de uma Cidade Portuária Vítor Silva Dias / João Pedro Bernardes / Celso Candeias / Cristina Tété Garcia

1413 No Largo das Mouras Velhas em Faro (2017): novas evidências da necrópole norte de Ossonoba e da sua ocupação medieval Ricardo Costeira da Silva / Paulo Botelho / Fernando Santos / Liliana Nunes

1429 Instrumentos de pesca recuperados numa fábrica de salga em Ossonoba (Faro) Inês Rasteiro / Ricardo Costeira da Silva / Paulo Botelho

1439 A Necrópole Romana do Eirô, Duas Igrejas (Penafiel): intervenção arqueológica de 2016 Laura Sousa / Teresa Soeiro

1457 Ritual, descarte ou afetividade? A presença de Canis lupus familiaris na Necrópole Noroeste de Olisipo (Lisboa)

Beatriz Calapez Santos / Sofia Simões Pereira / Rodrigo Banha da Silva / Sílvia Casimiro / Cleia Detry / Francisca Alves Cardoso

1467 Dinâmicas económicas em Bracara na Antiguidade Tardia Diego Machado / Manuela Martins / Fernanda Magalhães / Natália Botica

1479 Cerâmicas e Vidros da Antiguidade Tardia do Edifício sob a Igreja do Bom Jesus (Vila Nova de Gaia) Joaquim Filipe Ramos

1493 Novos contributos para a topografia histórica de Mértola no período romano e na Antiguidade Tardia Virgílio Lopes

\section{8. Época Medieval}

1511 Cerâmicas islâmicas no Garb setentrional "português": algumas evidências e incógnitas Constança dos Santos / Helena Catarino / Susana Gómez / Maria José Gonçalves / Isabel Inácio / Gonçalo Lopes / Jacinta Bugalhão / Sandra Cavaco / Jaquelina Covaneiro / Isabel Cristina Fernandes / Ana Sofia Gomes 
1525 Contributo para o conhecimento da cosmética islâmica, em Silves, durante a Idade Média Rosa Varela Gomes

1537 Yábura e o seu território - uma análise histórico-arqueológica de Évora entre os séculos VIII-XII José Rui Santos

1547 A encosta sul do Castelo de Palmela - resultados preliminares da escavação arqueológica Luís Filipe Pereira / Michelle Teixeira Santos

1559 A igreja de São Lourenço (Mouraria, Lisboa): um conjunto de silos e de cerâmica medieval islâmica

Andreia Filipa Moreira Rodrigues

1571 O registo material de movimentações populacionais no Médio Tejo, durante os séculos XII-XIII. Dois casos de "sunken featured buildings", nos concelhos de Cartaxo e Torres Novas Marco Liberato / Helena Santos / Nuno Santos

1585 O nordeste transmontano nos alvores da Idade média. Notas para reflexão Ana Maria da Costa Oliveira

1601 Sepulturas escavadas na rocha do Norte de Portugal e do Vale do Douro: primeiros resultados do Projecto SER-NPVD

Mário Jorge Barroca / César Guedes / Andreia Arezes / Ana Maria Oliveira

1619 "Portucalem Castrum Novum" entre o Mediterrâneo e o Atlântico: o estudo dos materiais cerâmicos alto-medievais do arqueossítio da rua de D. Hugo, nํ. 5 (Porto) João Luís Veloso

1627 A Alta Idade Média na fronteira de Lafões: notas preliminares sobre a Arqueologia no Concelho de Vouzela

Manuel Luís Real / Catarina Tente

1641 Um conjunto cerâmico medieval fora de portas: um breve testemunho aveirense Susana Temudo

${ }_{1651}$ Os Lóios do Porto: uma perspetiva integrada no panorama funerário da Baixa Idade Média à Época Moderna em meios urbanos em Portugal

Ana Lema Seabra

1659 O Caminho Português Interior de Santiago como eixo viário na Idade Média Pedro Azevedo

1665 Morfologia Urbana: Um exercício em torno do Castelo de Ourém André Donas-Botto / Jaqueline Pereira

1677 Intervenção arqueológica na Rua Marquês de Pombal/Largo do Espírito Santo (Bucelas, Loures)

Florbela Estêvão / Nathalie Antunes-Ferreira / Dário Ramos Neves / Inês Lisboa

1691 O Cemitério Medieval do Poço do Borratém e a espacialidade funerária na cidade de Lisboa Inês Belém / Vanessa Filipe / Vasco Noronha Vieira / Sónia Ferro / Rodrigo Banha da Silva

1705 Um Espaço Funerário Conventual do séc. XV em Lisboa: o caso do Convento de São Domingos da Cidade Sérgio Pedroso / Sílvia Casimiro / Rodrigo Banha da Silva / Francisca Alves Cardoso

\section{9. Época Moderna e Contemporânea}

1721 Arqueologia Moderna em Portugal: algumas reflexões críticas em torno da quantificação de conjuntos cerâmicos e suas inferências históricas e antropológicas Rodrigo Banha da Silva / André Bargão / Sara da Cruz Ferreira

1733 Faianças de dois contextos entre os finais do século XVI e XVIII do Palácio dos Condes de Penafiel, Lisboa

Martim Lopes / Tomás Mesquita 
1747 Um perfil de consumo do século XVIII na foz do Tejo: O caso do Mercado da Ribeira, Lisboa Sara da Cruz Ferreira / Rodrigo Banha da Silva / André Bargão

1761 Os Cachimbos dos Séculos XVII e XVIII do Palácio Mesquitela e Convento dos Inglesinhos (Lisboa)

Inês Simão / Marina Pinto / João Pimenta / Sara da Cruz Ferreira / André Bargão / Rodrigo Banha da Silva

1775 "Tomar os fumos da erua que chamão em Portugal erua sancta». Estudo de Cachimbos provenientes da Rua do Terreiro do Trigo, Lisboa

Miguel Martins de Sousa / José Pedro Henriques / Vanessa Galiza Filipe

1787 Cachimbos de Barro Caulínitico da Sé da Cidade Velha (República de Cabo Verde)

Rodrigo Banha da Silva / João Pimenta / Clementino Amaro

1801 Algumas considerações sobre espólio não cerâmico recuperado no Largo de Jesus (Lisboa) Carlos Boavida

1815 Adereços de vidro, dos séculos XVI-XVIII, procedentes do antigo Convento de Santana de Lisboa (anéis, braceletes e contas)

Joana Gonçalves / Rosa Varela Gomes / Mário Varela Gomes

1837 Da ostentação, luxo e poder à simplicidade do uso quotidiano: arqueologia e simbologia de joias e adornos da Idade Moderna Portuguesa Jéssica Iglésias

1849 Os amuletos em Portugal - dos objetos às superstições: o coral vermelho Alexandra Vieira

1865 Cerâmicas de Vila Franca de Xira nos séculos XV e XVI Eva Pires

1879 «Não passa por teu o que me pertence». Marcas de individualização associadas a faianças do Convento de Nossa Senhora de Aracoeli, Alcácer do Sal Catarina Parreira / Íris Fragoso / Miguel Martins de Sousa

1891 Cerâmica de Leiria: alguns focos de produção

Jaqueline Pereira / André Donas-Botto

1901 Os Fornos na Rua da Biquinha, em Óbidos Hugo Silva / Filipe Oliveira

1909 A casa de Pêro Fernandes, contador dos contos de D. Manuel I: o sítio arqueológico da Silha do Alferes, Seixal (século XVI) Mariana Nunes Ferreira

1921 O Alto da Vigia (Sintra) e a vigilância e defesa da costa Alexandre Gonçalves / Sandra Santos

1937 O contexto da torre sineira da Igreja de Santa Maria de Loures Paulo Calaveira / Martim Lopes

1949 A Necrópole do Hospital Militar do Castelo de São Jorge e as práticas funerárias na Lisboa de Época Moderna Susana Henriques / Liliana Matias de Carvalho / Ana Amarante / Sofia N. Wasterlain

1963 SAND - Sarilhos Grandes Entre dois Mundos: o adro da Igreja e a Paleobiologia dos ossos humanos recuperados

Paula Alves Pereira / Roger Lee Jesus / Bruno M. Magalhães

1975 Expansão urbana da vila de Cascais no século XVII e XVIII: a intervenção arqueológica na Rua da Vitória no 15 a 17

Tiago Pereira / Vanessa Filipe

1987 Novos dados para o conhecimento do Urbanismo de Faro em época Moderna Ana Rosa 
1995 Um exemplo de Arqueologia Urbana em Alcoutim: o Antigo Edifício dos CTT Marco Fernandes / Marta Dias / Alexandra Gradim / Virgílio Lopes / Susana Gómez Martínez

2007 Palácio dos Ferrazes (Rua das Flores/Rua da Vitória, Porto): a cocheira de Domingos Oliveira Maia

Francisco Raimundo

2021 As muitas vidas de um edifício urbano: História, Arqueologia e Antropologia no antigo Recreatório Paroquial de Penafiel Helena Bernardo / Jorge Sampaio / Marta Borges

2035 O convento de Nossa Senhora da Esperança de Ponta Delgada: o contributo da arqueologia para o conhecimento de um monumento identitário João Gonçalves Araújo / N’Zinga Oliveira

2047 Arqueologia na ilha do Corvo... em busca da capela de Nossa Senhora do Rosário Tânia Manuel Casimiro / José Luís Neto / Luís Borges / Pedro Parreira

2059 Perdidos à vista da Costa. Trabalhos arqueológicos subaquáticos na Barra do Tejo Jorge Freire / José Bettencourt / Augusto Salgado

2071 Arqueologia marítima em Cabo Verde: enquadramento e primeiros resultados do projecto CONCHA

José Bettencourt / Adilson Dias / Carlos Lima / Christelle Chouzenoux / Cristóvão Fonseca / Dúnia Pereira / Gonçalo Lopes / Inês Coelho / Jaylson Monteiro / José Lima / Maria Eugénia Alves / Patrícia Carvalho / Tiago Silva

2085 Trabalhos arqueológicos na Cidade Velha (Ribeira Grande de Santiago, Cabo Verde): reflexões sobre um projecto de investigação e divulgação patrimonial André Teixeira / Jaylson Monteiro / Mariana Mateus / Nireide Tavares / Cristovão Fonseca / Gonçalo C. Lopes / Joana Bento Torres / Dúnia Pereira / André Bargão / Aurélie Mayer / Bruno Zélie / Carlos Lima / Christelle Chouzenoux / Inês Henriques / Inês Pinto Coelho / José Lima / Patrícia Carvalho / Tiago Silva

2103 A antiga fortificação de Quelba / Khor Kalba (E.A.U.). Resultados de quatro campanhas de escavações, problemáticas e perspectivas futuras Rui Carita / Rosa Varela Gomes / Mário Varela Gomes / Kamyar Kamyad

2123 Colónias para homens novos: arqueologia da colonização agrária fascista no noroeste ibérico Xurxo Ayán Vila / José Mạ . Señorán Martín 


\title{
O ALTO DA VIGIA (SINTRA) E A VIGILÂNCIA E DEFESA DA COSTA
}

\author{
Alexandre Gonçalves ${ }^{1}$, Sandra Santos ${ }^{2}$
}

\begin{abstract}
RESUMO
O Alto da Vigia localiza-se numa arriba sobranceira ao mar junto à foz do rio de Colares, em Sintra, tendo sido identificados no local vestígios de um santuário romano, de um ribat islâmico e de uma vigia da costa de época moderna. Apresentam-se aqui algumas materialidades relativas a esta última ocupação, datável do início do século XVI até à primeira metade do XIX, um período de vários séculos durante o qual o sítio integrou um sistema de vigilância do litoral.

Para além da escavação arqueológica, a realização de prospeções e a consulta de fontes históricas, permitiu adicionar novos elementos relacionados com a vigilância do litoral da região a Norte do estuário do Tejo entre os séculos XVI e XIX.

Palavras-chave: Vigia moderna, Defesa costeira, Sintra, Colares.
\end{abstract}

\begin{abstract}
The archaeological site of Alto da Vigia is located in the mouth of the river of Colares, in the municipality of Sintra, and traces of a Roman sanctuary, an Islamic ribat and a coastal surveillance shelter have been identified. We now present some materialities from the latter occupation, dating back from the beginning of the $16^{\text {th }}$ to the $19^{\text {th }}$ century, a long period during which the site had an important role in the defence and surveillance of the coast.

The research of old cartography and archive documentation, complemented with archaeological survey, allowed the identification of new data related to coastal surveillance in the northern region of the Tagus River between the $16^{\text {th }}$ and $19^{\text {th }}$ centuries.
\end{abstract}

Keywords: Lookout point, Coastal defence, Sintra, Colares.

O presente trabalho encontra-se dividido em duas partes. Na primeira é feito o enquadramento geográfico e histórico do sítio, seguido da apresentação dos contextos e materiais arqueológicos relativos à vigia de época moderna. Na segunda parte relacionam-se aquelas evidências com informações recolhidas em documentação antiga, contextualizando o Alto da Vigia no âmbito da vigilância e defesa da costa na área a Norte do rio Tejo entre os séculos XVI e XIX.

\section{O SÍTIO ARQUEOLÓGICO DO ALTO DA VIGIA}

O Alto da Vigia localiza-se numa plataforma sobranceira ao mar na margem esquerda da foz do

1. Município de Sintra / UNIARQ - Universidade de Lisboa.

2. Município de Cascais. rio de Colares, junto à Praia das Maçãs, em Sintra. Corresponde a um local com uma posição geográfica estratégica, já que uma reentrância na linha de costa deu origem a que no passado ali se formasse um esteiro de mar (Daveau, 1994, p. 25) que possibilitava o acesso de embarcações ao interior do território, o que terá sucedido pelo menos até ao final da Idade Média (Cardim Ribeiro, 2019, p. 9o; Caetano, 200o, p. 13 e seguintes). O progressivo assoreamento da foz impediu aquele tipo de navegação a partir da época moderna, altura em que passou a ser possível apenas o desembarque no areal entretanto formado, continuando o local a ser utilizado como zona de desembarque e de entrada e escoamento de produtos (Figura 1). 
A importância da foz do rio de Colares encontra-se refletida na sua representação em alguma cartografia antiga, geralmente de escala muito grande e na qual se incluem apenas os locais mais significativos. Com efeito, aquele curso de água figura no Portugalliae quae olim Lusitania, de 156o (Secco, 1560), mas também em mapas dos séculos seguintes.

Será precisamente a sua implantação a determinar as distintas ocupações identificadas no Alto da Vigia em diferentes épocas, nomeadamente do santuário romano dedicado ao Sol, à Lua e ao Oceano (Cardim Ribeiro, 2019), do ribat $^{3}$ em época islâmica e de um edifício de vigia usado nas épocas moderna e contemporânea.

As referências mais antigas que temos acerca da existência de vestígios naquele local remontam a 1505 e são da autoria de Valentim Fernandes, também conhecido por Valentinus Moravus, que terá integrado o séquito que acompanhou D. Manuel quando o monarca se deslocou àquele local ermo do litoral sintrense no dia 9 de agosto de 1505, a propósito do aparecimento de inscrições do referido santuário romano (Cardim Ribeiro, 2016, p. 140).

Reconhecida na época a importância da descoberta, as ditas inscrições passam a integrar os itinerários epigráficos do século XVI, sendo registadas, nomeadamente, por André de Resende e Francisco d'Ollanda, tendo este último, décadas depois, feito um desenho dos vestígios que terá observado ( $D a$ Fabrica que falece ha Cidade de Lysboa, 1571).

Com o passar do tempo, a localização exata do santuário no litoral sintrense acaba por se perder, até que os trabalhos arqueológicos iniciados em 2008 permitiram não só confirmar a sua localização, como identificar ocupações posteriores do local e que eram desconhecidas até então.

No início da intervenção arqueológica afloravam à superfície do terreno o topo de estruturas, associadas a fragmentos de telha e cerâmica de época moderna. Estas evidências e o registo do topónimo vigia num sítio com aquela implantação, deixavam já antever a possibilidade da existência de uma estrutura relacionada com a vigilância da costa.

3. Da ocupação de época islâmica foram escavados dois edifícios, um deles uma mesquita com $12,50 \mathrm{~m}$ por $4,5 \mathrm{~m}$, com um mihrab centrado e orientado $130^{\circ}$ a Sudeste, $\operatorname{com} 1,80 \mathrm{~m}$ de largura e 1,5 $\mathrm{m}$ de profundidade; um enterramento de rito islâmico que faz parte de uma necrópole que se prolonga para lá dos limites da escavação e da qual se identificaram já 6 sepulturas; 3 silos de armazenamento.
A escavação dos vestígios assinalados revelou que correspondiam aos alicerces de uma vigia construída no início do século XVI que teve pelo menos duas remodelações, a primeira entre o início e meados do século XVIII, a outra já no final daquela centúria ou mais provavelmente no início da seguinte.

A vigia foi implantada junto à arriba e não no sítio de maior altitude da plataforma onde a mesma está localizada, que se situa numa área mais afastada da linha de costa, num sítio onde se regista o topónimo "Vigia Velha de Colares" e de onde se tem visibilidade quer para a foz do rio, quer para o interior do território em direção à vila de Colares. Apesar de no local o denso coberto vegetal não permitir aferir a eventual presença de vestígios, as estruturas visíveis parecem corresponder a simples muros de limite de propriedade.

\subsection{A construção da vigia no início do século XVI} Quando se abriram as valas para os alicerces da vigia, na areia que cobria os níveis de derrube dos edifícios islâmicos, terão sido identificados materiais lapidares romanos - inscrições e elementos arquitetónicos - que foram reutilizados como simples material de construção nas paredes de uma mesquita, sobre cujas ruínas a nova estrutura quinhentista foi em parte edificada.

Para além das fundações, registaram-se outras valas cuja configuração acompanha o alinhamento das paredes da mesquita, estando a sua abertura relacionada com a extração das pedras daquelas estruturas, possivelmente para as reutilizar na vigia que ali se estava a edificar. Esta ação resultou no desmonte quase integral do edifício islâmico, tendo sido identificados na escavação arqueológica ainda alguns negativos nos locais de onde foram extraídos os blocos. Com efeito, nos depósitos de preenchimento daquelas valas recuperaram-se grandes quantidades de elementos lapidares romanos muito fragmentados, alguns conservando ainda vestígios de inscrição, que resultam da sua segmentação in loco para criar peças mais pequenas.

A sequência estratigráfica acima descrita parece corresponder ao relato de Valentim Fernandes nas cartas que enviou a Hieronymus Münzer e a Konrad Peutingernas - sendo a remetida a este último datada de 16 de agosto de 1505 - nas quais descreve que «No ano 1505 (...) na base do promontório da Lua, que o vulgo chama Roca de Sintra, junto à costa do Mar Oceano, descobriram-se debaixo da terra (...) três 
colunas de pedra de forma quadrada, com caracteres romanos de grande antiguidade» que dali foram retiradas "utilizando um ferro e com cuidado, de entre as pedras com que estavam misturadas no terreno" (Cardim Ribeiro, 2016, p. 140). O já referido desenho de Francisco d'Ollanda situa as descobertas na «foz do ryo de Colares (...) sobre hu piqueno outeiro junto do Mar Oçeano" (Ibidem. p. 141), o que as escavações em curso permitiram confirmar.

A recolha, no depósito de enchimento da vala de fundação da vigia, de um ceitil datável de $1499 \mathrm{em}$ diante $^{4}$, (Figura 8, n. 3 ), permite enquadrar a sua construção no início do século XVI, próxima, assim, ao relato de Valentim Fernandes. O restante conjunto artefactual associado a este momento de construção é constituído por escassos fragmentos de cerâmica, essencialmente louça vermelha, dois dos quais permitem a sua reconstituição formal. A reduzida dimensão preservada de um bordo com pequeno espessamento interno dificulta a sua atribuição tipológica (Figura 8, n.ำ 1), reconhecendo-se, no entanto, algumas semelhanças com panelas datáveis do século XVI recuperadas em Cascais (Cardoso \& Rodrigues, 1999, p. 201) e Palmela (Fernandes \& Carvalho, 1995, pp. 235-236). A segunda peça corresponde a uma panela de bordo com pequena aba de secção retangular e colo direito (Figura 8, n.․ 2), com paralelos próximos em formas conhecidas para o século XVI, por exemplo, em Cascais (Cardoso \& Rodrigues, 1999, p. 201; Idem, 1991, pp. 581 e 583; Cardoso \& Encarnação, 199o, Est. VI-VII) e Palmela (Fernandes \& Carvalho, 1995, pp. 235-236).

O edifício da vigia apresentava uma planta aproximadamente retangular, com cerca de $6 \mathrm{~m}$ por $4,5 \mathrm{~m}$, sendo os seus alicerces construídos usando blocos de calcário com formas muito irregulares ligados por argila. Alguns foram assentes sobre materiais dos níveis de derrube da mesquita, enquanto outros se encontravam diretamente dispostos sobre os já referidos depósitos de areia usados para preencher as valas relacionadas com o desmonte das paredes da mesquita, acima descritas.

No exterior da parede Sul da vigia foi adossada uma estrutura maciça de pedra com aproximadamente

4. Ceitil de Dom Manuel compatível quanto a tipologia no "Grupo 5" definido por Magro (1986, pp. 45-46 e 208, exemplar-tipo no 5.1.6), que reúne os ceitis manuelinos cunhados a partir de inícios de 1499 (Cardim Ribeiro, 2016, p. 140, nota 5).
$3 \mathrm{~m}$ de comprimento e $1 \mathrm{~m}$ de largura, que poderá corresponder às fundações de uma escada pétrea que conduziria a um ponto de observação mais elevado, o que não implica necessariamente a existência de um terraço. Com efeito, durante os trabalhos arqueológicos foram identificados vestígios de derrubes de cobertura em telha associados às distintas fases de abandono. Por outro lado, a existência de uma tal plataforma na cobertura obrigaria a que o edifício fosse provavelmente mais alto, por forma a acomodar a necessária abóbada de suporte, colocando-se ainda a questão de saber até que ponto os seus alicerces - pouco profundos, construídos sem argamassa e parcialmente assentes em areia solta suportariam a carga introduzida por uma estrutura daquele tipo.

Exemplos de estruturas de vigia com terraço acessível através de escada exterior encontram-se, por exemplo, na vigia da Parede (Figura 4), que terá sido demolida no final da década de 1930 (AHMCSC/ CMC/C-A/O29/94/14) e naquela que ainda subsiste junto à Boca do Inferno, ambas em Cascais, porém de cronologia mais tardia. A primeira surge assinalada num mapa publicado em Inglaterra em 1810 (BND/PURL21797), encontrando-se também representada no levantamento geológico da costa efetuado por Carlos Ribeiro no início da segunda metade do século XIX ${ }^{5}$ (Ribeiro, 1949, Pl. VII), enquanto para a segunda, a referência documental mais antiga data de 1805 , apesar de a sua construção poder remontar ao final do XVIII (Boiça, Barros \& Ramalho, 2001, p. 162).

Durante a primeira fase de ocupação da vigia da foz de Colares não foram identificados vestígios da existência de um piso estruturado, por exemplo, com argila, madeira ou pedra, sendo a circulação efetuada diretamente sobre a areia, a qual seria possivelmente coberta com material de origem vegetal para facilitar a passagem, que naturalmente não se preservou no registo arqueológico.

Os vestígios desta fase de utilização materializaram-se no registo arqueológico através da formação de um nível com quantidades significativas de conchas e alguma cerâmica, materiais que se encontravam misturados com a areia que constituía a superfície de circulação.

5. Na edição daquela obra, George Zbyszewski indica como datas prováveis para a realização daqueles levantamentos os anos entre 1857 e 1868 . 
O conjunto artefactual recuperado naquele contexto é constituído essencialmente por louça vermelha, destacando-se a presença de panelas, que correspondem à forma mais frequente na cerâmica de época moderna em Lisboa (Casimiro \& Valongo, 2017, p. 1836). As peças deste depósito do Alto da Vigia têm bordos com pequena aba horizontal de secção retangular (Figura 8, n..ㅇ 5,7 e 9) e trapezoidal (Figura 8, n.o.s 6 e 8), tendo sido também recolhido um fragmento de parede com uma característica asa torça. Correspondem a formas com grande longevidade, que se enquadram nas tipologias conhecidas para os séculos XVII e XVIII (Ibidem, p. 1844; Casimiro, 2019, p. 238; Fernandes \& Carvalho, 1995, pp. 235-236). Recolheu-se ainda um bordo de pasta vermelha com vestígios de fogo nas duas superfícies, correspondendo a uma grande panela ou mesmo a um fogareiro (Figura 8, no .4 ).

Entre os referidos materiais encontram-se também vários fundos planos de panelas e de contentores para líquidos, nomeadamente de cântaros (Figura 8, n.․ำ 10 14).

Sobre aquele nível de utilização formou-se um depósito com grandes quantidades de carvão, que dificilmente se justificará com a simples realização de fogueiras no local. Tais vestígios distribuem-se de forma relativamente homogénea por todo o interior do edifício, prolongando-se para o seu exterior, onde encostam nas paredes Norte e Este (Figuras 3 e 5).

As suas características são compatíveis com um episódio de incêndio, sobre o qual se formou depois o derrube do telhado que assinala o fim da primeira fase de utilização da vigia. A presença de alguma cerâmica queimada reforça a possibilidade de um abandono rápido, sem que, no entanto, se registem quaisquer outros elementos concretos que permitam a sua associação a um eventual episódio bélico relacionado com a natureza e funcionalidade do edifício.

\subsection{Reformulação da vigia no século XVIII}

A reconstrução do edifício terá ocorrido pouco tempo depois do seu colapso parcial, sendo as telhas do derrube da cobertura, acima descrita, utilizadas como base para criação de uma superfície regular sobre a qual se dispôs uma camada de argila, criando assim um piso de circulação estruturado sobre os níveis de abandono da primeira ocupação do edifício. Este pavimento encontra-se associado à introdução de uma nova estrutura apoiada ao longo de toda a extensão da parede Sul do edifício (Figura 2, UE
349), com aproximadamente $1 \mathrm{~m}$ de largura, construída com blocos de calcário de formas irregulares, não sendo clara a sua funcionalidade. Na argila usada para ligar os blocos que a constituíam, foi recuperada uma moeda de D. João V cunhada em 1734 (Figura 8, n.ํำ 15).

Entre os fragmentos de cerâmica misturados no sedimento utilizado para construir o novo piso, encontrava-se um bordo de faiança decorado com faixa barroca contendo motivos de folha de acanto (Figura 8, n.․ 18 ), datável da segunda metade do século XVII a início do seguinte (Casimiro, 2013, p. 362). Esta peça, mas sobretudo o numisma atrás referido, permitem enquadrar a primeira reformulação da vigia no segundo quartel do século XVIII em diante, cronologia que se pode prolongar por meados desta centúria se atendermos ao tempo de circulação da moeda e ao facto de a peça de faiança se encontrar já descartada quando é misturada na argila do piso.

Sabemos que para a época em causa se encontram documentados estragos noutros edifícios da região de Sintra, associados ao grande sismo de 1755, podendo ser colocada como possibilidade ser essa a causa do colapso e consequente reestruturação da vigia em meados do século XVIII.

\subsection{Reformulação do interior da vigia - fim do sé- culo XVIII/início do XIX}

Foi ainda possível documentar uma segunda intervenção de remodelação parcial da vigia que incluiu a introdução de duas novas estruturas no seu interior, feitas com recurso a pedras de calcário aparelhadas de forma muito rudimentar e sem qualquer vestígio de argamassa de ligação (Figura 2, UE 42). Os blocos vão sobrepor-se parcialmente à construção adicionada em meados do século XVIII (a UE 349, atrás descrita), mantendo-se em uso nesta fase o piso de circulação anteriormente construído.

A introdução das duas estruturas não parece corresponder à criação de um novo compartimento, já que os exíguos cerca de $50 \mathrm{~cm}$ de largura entre as duas paredes tornariam muito pouco funcional a sua utilização. Atendendo ainda à sua pouca solidez e à ausência de alicerces, podemos deduzir que as mesmas provavelmente não foram projetadas para ter grande altura, podendo, em alternativa, ser complementadas com outros materiais, como a madeira. Esta solução permitiria, por exemplo, criar uma plataforma assente na base de pedra e a escassa altura do chão, com uma área de cerca de $1 \mathrm{~m}$ de largura por 2,50 $\mathrm{m}$ 
de comprimento, que podia ser usada para armazenamento de equipamento ou mesmo o espaço para o necessário descanso dos vigias ${ }^{6}$.

Uma das pedras empregue naquelas estruturas assenta em fragmentos de uma tigela decorada com linhas concêntricas no fundo e no interior do bordo, com decoração estilizada no centro (Figura 8, n.ํㅜㄹ), datável da primeira metade do século XVIII, mas podendo alcançar os meados do século XIX (Casimiro, 2013, pp. 363-364). Considerando ainda os materiais apresentados para enquadrar cronologicamente a anterior fase de remodelação - que situamos genericamente em meados do século XVIII -, as alterações agora verificadas na vigia deverão, pois, situar-se entre o fim daquele século e o início do XIX.

Os vestígios de uso desta última fase de ocupação correspondem a um depósito com algumas conchas associadas a sedimentos com carvão, sem que tenha sido registada qualquer lareira estruturada. $\mathrm{O}$ conjunto artefactual ali recuperado é constituído por louça de cozinha não vidrada, reconhecendo-se uma panela de fabrico e perfil semelhante às peças da fase anterior, com bordo de seção retangular formando uma pequena aba (Figura 8, n. ${ }^{\circ}$ 17). Uma segunda panela tem o bordo de secção triangular e a sua pasta encontra-se bem depurada, distinguindo-se nesse aspeto do fabrico das demais peças com análogas funcões recolhidas no sítio. A superfície interna é de cor creme e a exterior apresenta tons de vermelho (Figura 8, n.ำ16).

A cobertura do edifício vai colapsar sobre os contextos acima descritos, formando um depósito com fragmentos de telha misturados com alguma argamassa do reboco das paredes, para além de vários pregos de ferro, possivelmente relacionados com o colapso das estruturas de madeira do telhado.

Posteriormente, sobre o derrube acima descrito irão acumular-se ainda ténues vestígios da frequentação do espaço - essencialmente conchas associadas a pequenas fogueiras - numa altura em que o edifício se encontraria já em estado parcial de ruína e sem telhado, mas possivelmente com algumas paredes erguidas, proporcionando ainda algum abrigo a uti-

6. Note-se que de acordo com o estipulado no «Regimento dos capitães-mores», de 1570, (Systema ou Collecção de Regimentos Reais, 1789, pp. 183-194) deverão estar de serviço nas vigias duas pessoas durante o dia e três durante a noite "os quaes velarão aos quartos» (Ibidem, p. 193), pressupondo-se a alternância entre períodos de vigia e de descanso. lizações mais esporádicas, provavelmente já não relacionadas com a função de vigilância.

Finalmente, é bem provável que a partir da segunda metade do século XIX em diante as paredes caiam sobre os últimos vestígios de utilização do espaço, dando origem a um contexto que se encontra muito perturbado por se encontrar muito próximo da superfície, no qual se misturam materiais de distintas cronologias.

\section{O ALTO DA VIGIA E A VIGILÂNCIA E DEFESA DA COSTA}

A vigilância da atual costa portuguesa foi uma necessidade sentida ao longo de diferentes épocas, remontando pelo menos ao período islâmico, por altura das primeiras incursões normandas de que há registo, no século IX (Pires, 2012, p. 243; Fernandes, 2005; Catarino, 2004, p. 267). O problema mantém-se nos séculos seguintes com os constantes ataques de piratas e corsários, responsáveis por inúmeros assaltos às povoações costeiras e embarcações visando a captura de bens e cativos, pelos quais se exigia resgaste (Alberto, 2010, p. 6).

$\mathrm{O}$ controlo da navegação junto à costa era feito a partir de pontos de observação estratégicos que podiam dispor de estruturas de apoio muito diversas, desde torres com vários metros de altura, como se verificou, por exemplo, no Algarve (Silva, 1998), até simples abrigos (Alarcão \& Barroca, 2012, pp. 4849). Tais locais constituíam «auxiliares de primeira importância (...) servindo de guardas avançadas no controlo e aviso dos movimentos de barcos inimigos, em operações de saque ou desembarque» (Boiça, Barros \& Ramalho, 2001, p. 162).

Importa salientar que, não obstante se registarem investimentos distintos na construção de estruturas de apoio à vigilância costeira, os locais de observação deverão manter-se os mesmos ao longo do tempo, por força da sua localização estratégica, uma vez que é precisamente essa característica geográfica que permite que os mesmos sítios integrem um sistema de transmissão de mensagens.

Da leitura do já referido "Regimento dos capitães-mores", de 1570, depreende-se que vigia designa, antes de mais, o local e as pessoas encarregues da vigilância, não estando a palavra associada a um tipo específico de construção. Por conseguinte, os vestígios materiais que subsistem daquela atividade são também necessariamente diversos, por vezes apenas 
detetáveis através da análise de documentação antiga, não sendo raros os casos em que apenas topónimos como Vigia, Atalaia, Vela, Facho, Azóia ${ }^{7}$, entre outros, testemunham a existência de sítios com esta função no passado (Alarcão \& Barroca, 2012, pp. 4849; figura 1).

Os vestígios identificados na foz do rio de Colares estavam integrados numa rede alargada de comunicações - através da qual se procurava acautelar a defesa do território e que funcionou pelo menos desde época islâmica - da qual faziam parte um conjunto diversificado de estruturas, desde simples locais de vigia a construções militares. As unidades deste sistema mais amplo não se encontravam sempre com o mesmo nível de alerta, que era acionado em épocas de maior perigo, verificando-se frequentemente que durante os períodos mais calmos a manutenção de alguns equipamentos era descurada (Boiça, Barros \& Ramalho, 2001, p. 16).

Na região a Norte da foz do Tejo podemos antever a existência deste sistema de comunicação, que certamente alcançaria Lisboa, através de um alvará régio de 1589, no qual se refere a necessidade do responsável por controlar as vigias entre Colares e Torres Vedras de manter "comonicasão e boa correspondencia no que toqa as ditas vigias» com a pessoa que exerce funções análogas na área imediatamente a Sul, em Cascais (AHMCSC/SCMC/A-A/oo2/o14/fl.1).

Apesar de a partir de alguns pontos de Sintra - como do seu castelo implantado na crista da serra - se alcançarem visualmente áreas tão amplas como a margem esquerda do Tejo, pelo facto de esta região estar "permanentemente mergulhada numa bruma que se não dissipa» (Coelho, 1989, p. 63) os sistemas de comunicação visual a longas distâncias podiam ser comprometidos, sendo então necessário um sistema de maior proximidade entre os distintos pontos de observação, constituídos essencialmente por vigias, que garantissem a eficaz passagem dos necessários sinais (Borges, 2017a, p. 36).

A comunicação entre os diferentes sítios integrados no mesmo sistema de vigilância seria feita através de

7. Na área da Azóia, a par do topónimo Atalaia, registam-se ainda junto ao farol do Cabo da Roca os microtopónimos Cruzeiro do Facho e Vigia da Roca. A Sul daquela zona, no Espigão das Ruivas, já no litoral de Cascais, os vestígios da Idade do Ferro, das épocas romana e islâmica estarão provavelmente relacionados com esta atividade naquele local (Encarnação \& Cardoso, 2017). "fumos», "fachos" (conforme Regimento de 1570) e rebate de sino, como se depreende de um decreto de 1646 que determina que os vigias em serviço na "Cabeça de Oitavos" (próximo do forte de São Jorge de Oitavos, em Cascais) deviam tocar a "rebate na hora de que se descobrirem de dez velas para cima", sendo nessas situações competência da Vila de Cascais e seu termo organizar e garantir a defesa. $\mathrm{Na}$ eventualidade de o número de velas ser superior a 20 deverão responder a um sinal diferente as companhias de Sintra e Colares. O referido sítio funcionou ainda em 1796 como local de retransmissão de mensagens vindas do Cabo da Roca por meio de bandeiras, destinadas a avisar quando fossem avistados "navios de mais de três mastros e esquadras de guerra» (Calixto, 1980, p. 151).

O conjunto de balas de chumbo para arcabuz recolhidas no Alto da Vigia (Figura 8, n.․19), atesta a presença daquelas armas de fogo para dissuadir eventuais desembarques, mas também possivelmente para dar o sinal de alerta perante alguma ameaça, conforme o disposto no referido Regimento de 1570. A análise de documentação antiga, complementada com prospeções arqueológicas, permitiu identificar vários locais de vigia na costa a Norte da foz do rio de Colares (Figura 1). No já citado trabalho de Carlos Ribeiro encontram-se registados os sugestivos topónimos de Alto da Vela e Ponta da Vigia, a Sul da foz da ribeira de Maceira, na Lourinhã (1949, Pl. I), certamente testemunhos de um passado ligado à vigilância costeira.

Já no atual concelho de Mafra, na descrição da povoação da Carvoeira numa obra do século XVIII, é referido que aquele local «tem tambem o privilegio para se não fazer nella Soldados, pela sentinela, que fazem os moradores em hum facho, que tem esta na foz do rio, pelo perigo de poderem alli desembarcar Mouros. Passa por esta Freguesia hum rio, chamado Rio grande do Porto" (Cardoso, 1751, p. 498).

Saliente-se que na foz do "Rio grande do Porto" (nome pelo qual o rio Lizandro era por vezes referido), à semelhança do verificado no rio de Colares, se formaria um pequeno braço de mar (Daveau, 1994, p. 25) que permitiria que a parte final daquele curso de água fosse navegável no passado (Cardim Ribeiro, 1983, p. 165) e onde foi também necessário instalar um ponto de vigia. A sua localização, porém, permanece incerta, correspondendo talvez ao outeiro onde se ergueu no início do século XIX um dos fortes das linhas de Torres. 
Seguindo para Sul, uma elevação na margem esquerda da foz da ribeira do Falcão regista atualmente o topónimo Vigia da Assafora, ainda que no local não sejam atualmente visíveis qualquer tipo de vestígios materiais.

Num mapa editado em Viena [1791] (UC/BGD/ NC-321) encontra-se referenciada a Atalaia do Magoito, que corresponderá provavelmente àquela que surge mais tarde identificada como "Vigia da Matta" numa colina junto à praia do Magoito. No local são visíveis as ruínas de um edifício de planta retangular, com cerca de $3 \mathrm{~m}$ de largura por $4 \mathrm{~m}$ de comprimento e paredes de o,65 $\mathrm{m}$ de espessura rebocadas no paramento exterior, que correspondem provavelmente aos vestígios daquela vigia. Conservam-se ainda aproximadamente $2 \mathrm{~m}$ de altura de parede no canto Sudoeste da estrutura, no topo da qual foi instalado um marco geodésico em 1945 (Figura 6).

\subsection{A foz do rio de Colares durante a época me-} dieval - Entre mouros e cristãos

O Alto da Vigia, pela sua localização estratégica, parece ter adquirido, desde cedo, relevância particular em contextos históricos pautados por uma franca instabilidade política e militar, como sucederia durante a época islâmica, quando no local são erigidas estruturas compatíveis com um ribat - sítios onde se conjuga a função religiosa com o controlo de pontos estratégicos para a defesa do território.

As evidências materiais ali recuperadas até ao momento atestam uma ocupação islâmica enquadrável nos séculos XI e XII, não dissociável da pressão cristã exercida a partir de Coimbra e da conquista da região de Sintra e Lisboa, em 1147. Embora não seja possível, com os dados atuais, determinar a cronologia do início da ocupação, é provável que seja anterior aos vestígios remanescentes se tivermos em conta as referências às investidas normandas na costa atlântica pelo menos desde o século IX (Fernandes, 2005; Pires, 2012, p. 243).

A espessa duna acumulada sobre os níveis de derrube dos dois edifícios islâmicos já escavados neste sítio arqueológico, sugere que os mesmos são abandonados e assim permaneceram até ao início do século XVI, quando a vigia é ali construída. Tal não significa, no entanto, que outras construções ainda não escavadas - mas cujos vestígios afloram à superfície e que a prospeção geofísica realizada deixa também antever - possam ter sido parcialmente adaptadas e usadas da segunda metade do século XII em diante como local de abrigo para os vigias que cumpriam a sua função neste lugar.

Note-se que no ribat da Arrifana, junto a Aljezur, igualmente implantado num sítio estratégico do litoral, se regista já em época cristã a utilização de uma mesquita como local de habitação. Aquela ocupação estará relacionada com a utilização do minarete como torre de vigia (Gomes \& Gomes, 2006, p. 336), que se mantém em uso até ao século XVIII (Idem, 2019, p.334).

A propósito das antigas ocupações da foz do rio de Colares, há ainda a destacar que na margem direita daquele curso de água, no subsolo da atual povoação da Praia das Maçãs, foram identificados vestígios de uma necrópole (Azevedo, 1907, pp. 100-101) possivelmente relacionada com um templo cristão, bem como evidências de habitações associadas a materiais datáveis dos séculos XIII e XIV, contextos compatíveis com a povoação de Mazanaria, referida num documento de 1220 (Costa, 1980, p. 62). $\mathrm{O}$ posterior abandono deste local junto à costa não será certamente alheio à insegurança verificada no litoral durante a Idade Média, problema que terá certamente contribuído, apesar das iniciativas régias tomadas no sentido de o minimizar, para o afastamento do povoamento das áreas costeiras (Andrade, 2005, p. 65), devendo ser ainda consideradas as dificuldades naturais decorrentes de viver na proximidade do mar (Marques, 1989, p. 10).

\subsection{A vigia de Colares - Da expansão marítima à guerra Liberal}

Com a expansão marítima portuguesa do século $\mathrm{XV}$ em diante verificou-se o incremento das ações de corso e pirataria, sendo tomadas iniciativas para debelar essa ameaça constante, entre as quais destacamos neste trabalho o "Regimento dos capitães-mores» de 1570, no qual se procura regulamentar e uniformizar a atividade das vigias, que já era praticada nas zonas costeiras (Feio, 2013, p. 59).

No citado documento é definido o funcionamento das vigias, determinando-se que as áreas costeiras "para que naõ recebaõ damno algum das continuas armadas dos cossarios (...) em todos os ditos lugares, portos de mar, haja vigias todo o veraõ, e em qualquer outro tempo de bonança, com que imigos possaõ desembarcar, ou fazer outros damnos (...). Os moradores de cada hum dos ditos lugares, portos de mar, seraõ obrigados a vigiar de dia nas pontas que mais descobrirem ao mar, e de noite nos por- 
tos, calhetas, praias, ou pedras em que parecer que os ditos inimigos poderaõ desembarcar» (Systema ou Collecção de Regimentos Reais, 1789, p. 192).

Atendendo às especificidades geográficas de cada região e reconhecendo que "he necessario saber-se os lugares mais convenientes, e em que melhor, e mais seguramente se poderaõ pôr as ditas vigias" ordena-se que as pessoas designadas para o efeito «vaõ (...) á Camara da Cidade, Villa, ou Lugar de que for Capitaõ, e faça juntar nella os Juizes, Officiaes, e Pessoas do Regimento, e as mais pessoas moradores na dita Villa, que lhe parecer necessario, e com elles repartirá onde se devem pôr as ditas vigias, assim de dia como de noite», devendo as localizações definidas ter "assento no livro da Camera» (Ibidem).

A necessidade de vigilância da costa acentua-se durante as décadas de domínio castelhano dos territórios portugueses (1580-1640), uma vez o reino se vê envolvido nos conflitos da coroa espanhola com outros países europeus, estando documentados inúmeros relatos de ataques de navios ingleses, franceses e holandeses ao nosso litoral (Silva, 1985: 311 ). É neste contexto, através de um alvará régio de 1589 , que António de Mello de Castro ${ }^{8}$ é encarregue da «superintendencia da gente que a na villa de Collares e seu termo e no termo da villa de Cintra e nas villas e termos de mafara iriçeira (...) athe o termo da villa de Torres Vedras (...) para fazer vigiar de dia e de noite com fachos (...) tendo Com a pesoa a cujo cargo esta a jente de Casqaes e com dom martinho soares toda a comonicasão e boa correspondencia no que toqa as ditas vigias» (AHMCSC/SCMC/A-A/002/014/fl.1).

Através de uma adenda feita a este documento por "manoell dias de payva sprivão da camara» da "vyla de collares e seu termo", ficamos a saber que "amtonio alluarez caualleyro fidallgo" "foj emlleyto pera capitam della e das vegias da costa desta vylla» (Ibidem, fl. 1v.).

Como se viu atrás, o registo arqueológico atesta que a vigia da foz de Colares se encontrava ocupada nos séculos XVII e XVIII, período durante o qual o edifício sofre uma destruição e é de novo rapidamente reconstruído. Apesar de recolhidos fora do seu contexto arqueológico original, a presença de um prato decorado com faixa barroca contendo motivos de

8. Possivelmente da importante família que no início do século XVII adquiriu o edifício do antigo castelo de Colares para ali construir um palácio. folha de acanto (Figura 8, n.․․ 21) e alguns fragmentos de faiança com decorações vegetalistas, materiais datáveis dos XVII e XVIII, reforçam a ideia da ocupação do sítio durante estas centúrias.

Mais tarde, já no contexto dos acontecimentos em curso no centro da Europa, decorrentes da revolução francesa, é realizado em 1796 um levantamento das fortificações costeiras, a fim de averiguar a sua operacionalidade e o perigo de desembarque, concluindo-se que a Praia das Maçãs «está sem defença e não admite dezembarque por causa do mar arrebentar de longe sobre bancos de arêa móvilı. No entanto, cerca de $1 \mathrm{~km}$ a Sul, a Praia Grande de Colares «está sem defença, e em toda ella se pode dezembarcar pois atualmente se fazem nella pescarias de batéis e redes de arrastar». Saliente-se, ainda, que no desenho que acompanha o documento, com a configuração da Praia das Maçãs, encontra-se representado um edifício no local correspondente à localização da vigia (BDR/DIE/8129-3-43).

Apesar do que é enunciado no documento acima referido sobre a dificuldade de desembarque na Praia das Maçãs, através de um requerimento apresentado em 1822 por um candidato ao emprego de vigia na dita praia, ficamos a saber que esse perigo era real, dada a "facelidade do desembarque que os Francezes no tempo em que occuparão o Reyno tanto Reconhecerão que sempre tiverão naquelle citio huma força Armada consideravel» (ANTT, Min. Reino, Mç. 759, Proc. 32, fl. 6).

Cerca de uma década volvida sobre o sobressalto provocado pelas invasões francesas, sabemos que em 1819 João Anastácio fora nomeado para o «Emprego de vigia da Praia das Maçans, para denunpciar qualquer desembarque que possa ali acontecer». Tal decisão decorre do facto de ali ter "havido e podem haver faceis dezembarques (...) precizando haver naquelle Lugar ou a elle muito proximo uma Pessoa capaz (...) para vigia da ditta Praia a fim de cuidar que a ela não se approxime vazo algum que se suspeite vir ou ter pasado por Pais infecionado de Peste ou da mesma suspeito" (Ibidem, fls. 1 e 11).

No verão de 1831, no contexto que antecede a guerra civil, o governo absolutista de D. Miguel determinou a realização de um levantamento das condições de defesa da costa, no qual se reconhece o perigo de desembarque de tropas na área compreendida entre a Praia das Maçãs e numa extensão de cerca de 2,5 km para Sul, até à Pedra de Alvidrar, propondo-se, em 
conformidade, a construção de várias baterias naquela zona, uma delas na foz de Colares.

No projeto que resulta do levantamento então feito, indica-se que a bateria da Praia das Maçãs não deverá ser construída com alvenaria permanente, propondo-se que o seu "parapeito fique formado de terras virgens revestido de lajes», por ser mais económica a sua reconstrução em caso de eventual derrocada provocada pela erosão costeira, decorrente das especificidades da geologia do local. Porém, no parecer posteriormente elaborado sobre este projeto, refere-se que tal estrutura «ainda que seja própria para bater os navios e lanchas do inimigo, não o parece para o bater na praia ou no desembarque (...) pelo que não julga satisfeito o quesito de defender o desembarquel, concluindo-se que a eficaz defesa da Praia das Maçãs teria de ser feita noutro local que não o indicado pelo referido projeto (AHM/Div.3/9/D1/36). Desconhece-se se tal bateria terá sido edificada. Atendendo a que nem no local proposto, nem em toda a área a Sul até à Pedra de Alvidrar se identificaram até ao momento quaisquer tipos de estruturas militares, devemos admitir que o projeto ficou por executar. Note-se que poucos meses depois da apreciação final daqueles planos de defesa da costa, datados do outono de 1831, as forças liberais desembarcaram no Mindelo.

$\mathrm{Na}$ já referida representação da costa traçada por Carlos Ribeiro no início da segunda metade do século XIX, verificamos que no pequeno outeiro da margem esquerda do rio de Colares se encontra figurado um edifício de telhado de duas águas designado de "Vigia de Collares» (Ribeiro, 1949, Pl. V; figura 7), atestando que a mesma se encontraria ainda erguida naquela época, cerca de três décadas passadas sobre os últimos acontecimentos para os quais encontrámos referências documentais sobre o sítio. A vigia da Praia das Maçãs terá entrado progressivamente em declínio a partir de meados do século XIX, à semelhança de outras estruturas relacionadas com a vigilância e a defesa da costa (Boiça, Barros \& Ramalho, 2001, p. 23).

Materiais recolhidos à superfície junto à vigia, como garrafas de grés ou um bordo de prato com decoração vegetalista estampada, provavelmente com o motivo "estátua", atestam, contudo, que o local foi frequentado durante a segunda metade do século XIX e início do século XX.

Num postal que se encontrava em circulação em 1912, é visível a vigia já arruinada com as paredes re- duzidas a cerca de um metro de altura (Gaspar, 2010, p.125), tendo estas sido posteriormente desmanteladas e as suas pedras reaproveitadas, à semelhança do que sucedera no passado, para novas construções, possivelmente, desta vez, para erguer muros de delimitação de terrenos.

De acordo com o que foi exposto ao longo deste texto, constata-se que no Alto da Vigia, na foz do rio de Colares, foi construído no início do século XVI um edifício de vigia ${ }^{9}$ sobre as ruínas de uma mesquita que integra o ribat existente neste local. A esta vigia primitiva que se arruinaria, sucederia uma outra, erguida ainda no decurso do século XVII ou já na centúria seguinte, situação que documenta a sua importância na rede de vigilância da linha de costa próxima a Lisboa, que se prolongaria até Oitocentos.

\section{AGRADECIMENTOS}

Ao Vítor Serrão e a Rita Sampaio da Nóvoa pela ajuda na transcrição do alvará régio; a Tânia Casimiro pela colaboração na classificação do espólio; ao Joaquim Boiça pelas sugestões a este trabalho; a Ana Neves pelo desenho dos materiais; ao Joel Marteleira pelo mapa e planta e à equipa de escavação do Alto da Vigia, na qual os estudantes e os voluntários têm tido um papel importante.

\section{FONTES HISTÓRICAS}

Arquivo Histórico Militar/Divisão 3/9/D1/36.

Arquivo Histórico Municipal de Cascais/Câmara Municipal de Cascais/C-A/O29/94/14.

Arquivo Histórico Municipal de Cascais/Coleção Antiga do Município/B/oo4/179.

Arquivo Histórico Municipal de Cascais/Santa Casa da Misericórdia de Cascais/A-A/oo2/14/2 fls.

Arquivo Nacional Torre do Tombo, Ministério do Reino, Maço 759, Proc. 32, 16 fls..

Biblioteca Nacional Digital, PURL21797.

Biblioteca Digital do Exército, Direção de Infraestruturas do Exército, 8129-3-43.

Universidade de Coimbra, Biblioteca Geral Digital, Nabais Conde-321.

9. Apesar de ter sido proposta uma cronologia mais antiga para a vigia da Foz de Colares (Borges, 2017b, pp. 252-253), os dados arqueológicos indicam que tal terá ocorrido apenas no início do século XVI. 


\section{BIBLIOGRAFIA}

ALARCÃO, Jorge; BARROCA, Mário, coord. (2012) - Dicionário de Arqueologia Portuguesa. Porto: Figueirinhas.

ALBERTO, Edite Maria da Conceição Martins (2010) - Um Negócio Piedoso: o Resgate de Cativos em Portugal na Época Moderna. Dissertação de doutoramento apresentada à Universidade do Minho. Braga.

ANDRADE, Amélia Aguiar (2005) - A estratégia régia em relação aos portos marítimos do Portugal medieval: o caso da fachada atlântica. In ARÍZAGA BOLUMBURU, Beatriz e SOLÓRZANO TELECHEA, Jesus A. eds. - Ciudades y villas portuarias del Atlântico en La Edad Media, Nájera. Encuentros Internacionales del Medievo - atas. Logroño: Gobierno de La Rioja, Instituto de Estudios Riojanos, pp. 57-89.

AZEVEDO, Pedro (1907) - Miscellanea: I - Notícias várias. Archeologo Português, Série I. XII, pp. 92-103.

BOIÇA, Joaquim Manuel F.; BARROS, Maria de Fátima R.; RAMALHO, Margarida de Magalhães (2001) - As Fortificações Marítimas da Costa de Cascais. Lisboa: Quetzal Editores.

BORGES, Marco (2017a) - A importância estratégica do conhecimento do território na formação de um sistema defensivo: o caso de Sintra (Portugal) durante o Período Islâmico. Anuario de Historia Regional y de las Fronteras. Bucamaranga, Vol. 22, no. 2 pp. 17-48.

BORGES, Marco (2017b) - Paisagem cultural marítima de Sintra: uma abordagem histórico-arqueológica. In FIDALGO, Pedro, coord., Estudos de paisagem. Lisboa: Instituto de História Contemporânea da FCSH-UNL, Vol. III, pp. 230-27.

CAETANO, Maria Teresa (200o) - Colares. Mem Martins: Câmara Municipal de Sintra.

CALliXTO, Carlos Pereira (1980) - Fortificações da Praça de Cascais a Ocidente da Vila. Separata da Revista Militar. Lisboa: Gráfica da Liga dos Combatentes.

CARDIM RIBEIRO, JOSÉ (1982-83) - Estudos historico-epigraficos em torno da figura de L. Iulius Maelo Caudicus. Sintria, 1-2, pp. 151-476.

CARDIM RIBEIRO, José (2016) - Ad antiquitates vestigandas. Destinos e itinerários antiquaristas nos campos olisiponenses ocidentais desde inícios a meados do século XVI. In González Germain, G., ed. - Peregrinationes ad inscriptiones colligendas. Estudios sobre epigrafía de tradición manuscrita. Actas do Seminário - Colóquio Saxosas vias terere. Hollando los Caminos de la Geografia Antigua (150o-170o). Barcelona, 2015. Barcelona: Universidat Autònoma, pp. 135-249.

CARDIM RIBEIRO, José (2019) - Escrever sobre a margem do Oceanus: epigrafia e religio no santuário do Sol poente (provincia Lusitania). Barcelona: (Sylloge Epigraphica Barcinonensis, Annexos 3).

CARDOSO, Guilherme; ENCARNAÇÃo, José (1990) Uma sondagem de emergência no casal do Geraldo (Estoril-Cascais). Arquivo de Cascais: Boletim cultural do município. Câmara Municipal de Cascais, 9, pp. 45-62.
CARDOSO, Guilherme; RODRIGUES, Severino (1991) Alguns tipos de cerâmica dos séculos XI a XVI encontrados em Cascais. In SILVA, Luís Alves da; MATEUS, Rui, eds. - A Cerâmica Medieval no Mediterrâneo Ocidental: atas do IV Congresso Internacional. Mértola: Campo Arqueológico de Mértola, pp. 575-585.

CARDOSO, Guilherme; RODRIGUES, Severino (1999) Tipologia e cronologia das cerâmicas dos séculos XVI, XVII e XIX encontradas em Cascais. Arqueologia Medieval. Porto: Afrontamento, 6, pp. 193-212.

CARDOSO, Padre Luís (1747-1751) - Diccionario geografico, ou noticia historica de todas as cidades, villas, lugares, e aldeas, rios, ribeiras, e serras dos Reynos de Portugal, e Algarve, com todas as cousas raras, que nelles se encontraõ, assim antigas, como modernas. Lisboa: na Regia Officina Sylviana e da Academia Real, 2 Vols.

CASIMIRO, Tânia Manuel (2013) - Faiança portuguesa: datação e evolução crono-estilística. Revista Portuguesa de Arqueologia. Lisboa. Vol.16, pp. 351-367.

CASIMIRO, Tânia (2019) - Materialidades quotidianas de Idade Moderna em Alhandra. Os contextos arqueológicos da escavação do Centro de Saúde. Cira-Arqueologia. Câmara Municipal de Vila Franca de Xira, 7.

CASIMIRO, Tânia; VALONGO, António (2017) - Uma lixeira nas Casas Nobres do Infantado. In Arqueologia em Portugal: 2017 Estado da Questão. Lisboa: Associação dos Arqueólogos Portugueses, pp. 1835-1848.

CATARINO, Helena (2004) - Breve sinopse sobre topónimos Arrábida na costa portuguesa. In FRANCO SÁNCHEZ, Francisco; EPLALZA, Míkel, eds., - La Rábita en el Islam. Estudios Interdisciplinares. Congressos Internacionals de Sant Carles de la Ràpita (1989, 1997). Sant Carles de la Ràpita/ Alacant: Ajuntament de Sant Carles de la Ràpita/Universitat d'Alacant, pp. 263-274.

COELHO, António Borges (1989) - Portugal na Espanha Árabe. Lisboa: Caminho, 2. ․ㅡ ed., vol. I.

COSTA, Francisco (1980) - O Paço Real de Sintra: Novos Subsídios para a sua História. Sintra: Câmara Municipal.

DAVEAU, Suzanne (1994) - A foz do Tejo, palco da história de Lisboa. In Lisboa Subterrânea. Lisboa: Museu Nacional de Arqueologia.

ENCARNAÇÃO, José d'e CARDOSO, Guilherme (2017) - O sítio arqueológico do Espigão das Ruivas (Cascais). Arqueologia em Portugal. 2017 - Actas do II Congresso de Arqueologia da Associação dos Arqueólogos Portugueses, realizado, em Lisboa, de 22 a 25 de Novembro de 2017. ARNAUD, José Morais e MARTINS, Andrea (Coord.).

FEIO, Gonçalo Couceiro (2013) - O ensino e a aprendizagem militares em Portugal e no Império, de D. João III a D. Sebastião: a arte portuguesa da guerra. Dissertação de doutoramento apresentada à Faculdade de Letras de Lisboa. Lisboa. Edição policopiada. 
FERNANDES, Isabel Cristina (2005) - Aspectos da litoralidade do Gharb al-Andalus. Os portos do baixo Tejo e do baixo Sado. Arqueologia Medieval. Porto: Afrontamento, 9, pp. 47-6o.

FERNANDES, Isabel Cristina; CARVALHO, Rafael António (1995) - Conjuntos Cerâmicos Pós-Medievais de Pal-

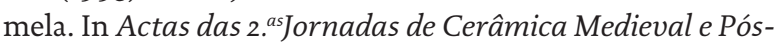
-medieval. Tondela, pp. 211-255.

GASPAR, Miguel; GASPAR, Nuno (2010) - Um Passeio de Cintra até ao Mar. Postais e Fotografias do Passado. [Lisboa]: Artlandia.

GOMES, Rosa V. \& Gomes, Mário V. (2006) - O Ribat da Arrifana (Aljezur, Algarve): Resultados das escavações arqueológicas no Sector 3 (2003/2004). Revista Portuguesa de Arqueologia. 9.2. Lisboa, pp. 329-352.

Idem (2019) - A necrópole do ribat da arrifana (Aljezur, Portugal). In Al-kitab. Juan Zozaya Stabel-Hansen. Madrid: Carmelo Fernández Ibáñez (ed.), pp. 343-352.

MARQUES, António Henrique de Oliveira (1989) - Carta da Vila de Cascais 1334: estudo e transcrição. Cascais: Câmara Municipal.

PIRES, Hélio (2012) - Incursões nórdicas no Ocidente Ibérico (844-1147): fontes, história e vestígios. Dissertação de doutoramento apresentada à Universidade Nova de Lisboa.

OLLANDA, Francisco d' (1571) - Da Fabrica que falece ha Cidade de Lysboa. [Lisboa, Biblioteca Nacional da Ajuda, códice 51/III/9.]

RIBEIRO, Carlos (1949) - Vues de la côte portugaise entre l'estuaire de la rivière de Maceira et Pedra do Frade a l'ouest de Cezimbra. Compil. e texto Georges Zbyszewski. Lisboa: Serviços Geológicos de Portugal.

SECCO, Fernando Alvares (156o) - Portugalliae quae olim Lusitania novissima \& exactissima descriptio. Roma. [s.n.].

SILVA, Celeste Nogueira (1998) - As torres de vigia do antigo Concelho de Faro. Anais do Município de Faro. Câmara Municipal de Faro, Vols. 27-28, pp. 117-140.

SILVA, Francisco Ribeiro da (1985) - O corso inglês e as populações do litoral lusitano (1580-1640). In Colóquio «Santos Graça» de etnografia marítima. Actas III. Povoamento. Administração. Aspectos sociais. Câmara Municipal da Póvoa de Varzim, pp. 311-339.

Systema ou Colleção de Regimentos Reais. Contèm os Regimentos Pertencentes a`Fazenda Real, Justiças e Militares (1789). Lisboa: Na Officina Patriacal de Francisco Luiz Ameno, Tomo V. 


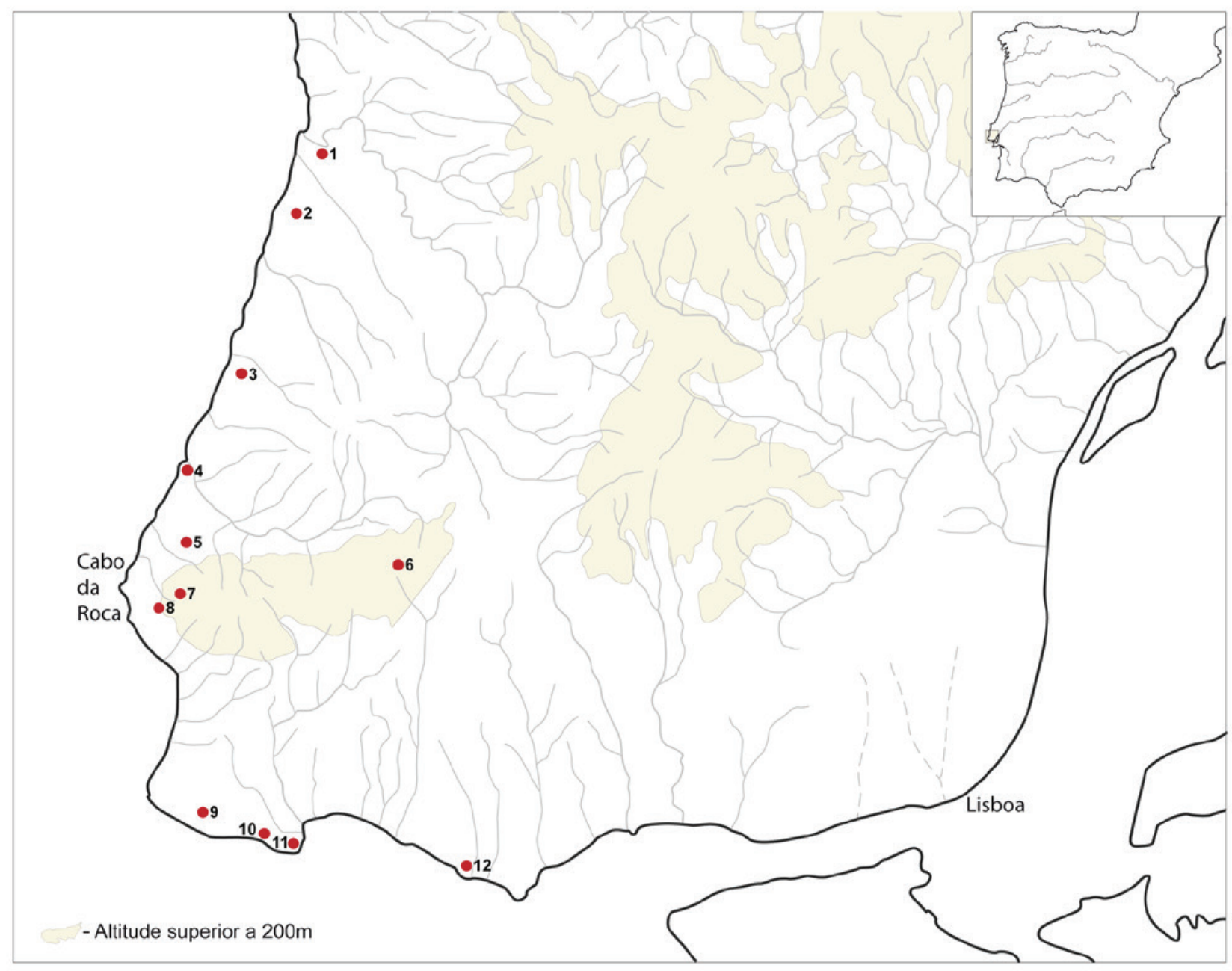

Figura 1 - Localização dos principais sítios referidos no texto: 1: Foz do Lizandro; 2: Vigia da Assafora; 3: Vigia da Mata/ Magoito; 4: Alto da Vigia; 5: Colares; 6: Sintra; 7: Atalaia; 8 Azóia; 9: Cabeça de Oitavos; 8: Vigia da Boca do Inferno; 10: Cascais; 11: Parede. Autor: Joel Marteleira. 


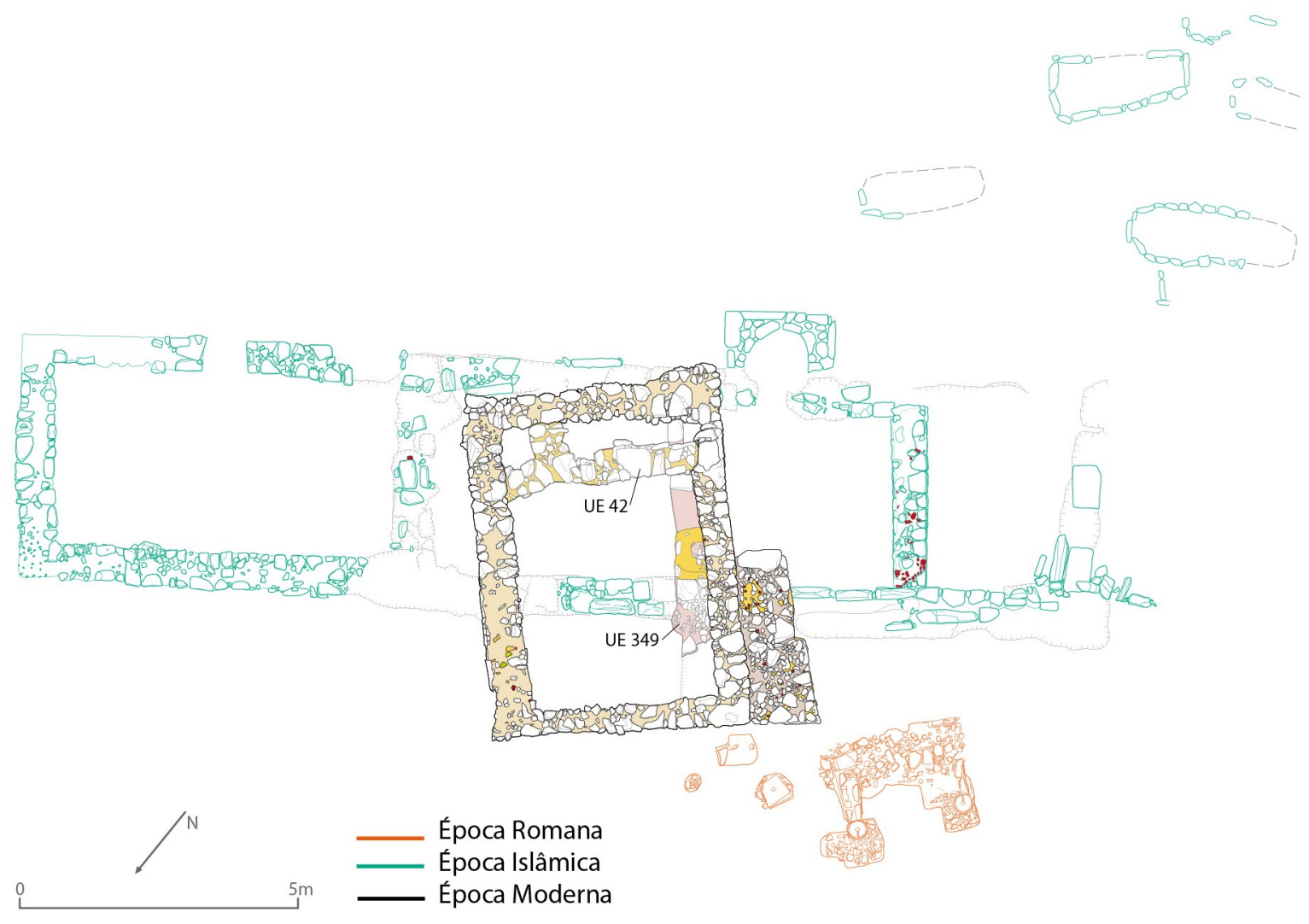

Figura 2 - Planta com os principais vestígios identificados no sítio arqueológico do Alto da Vigia. Autor: Joel Marteleira.

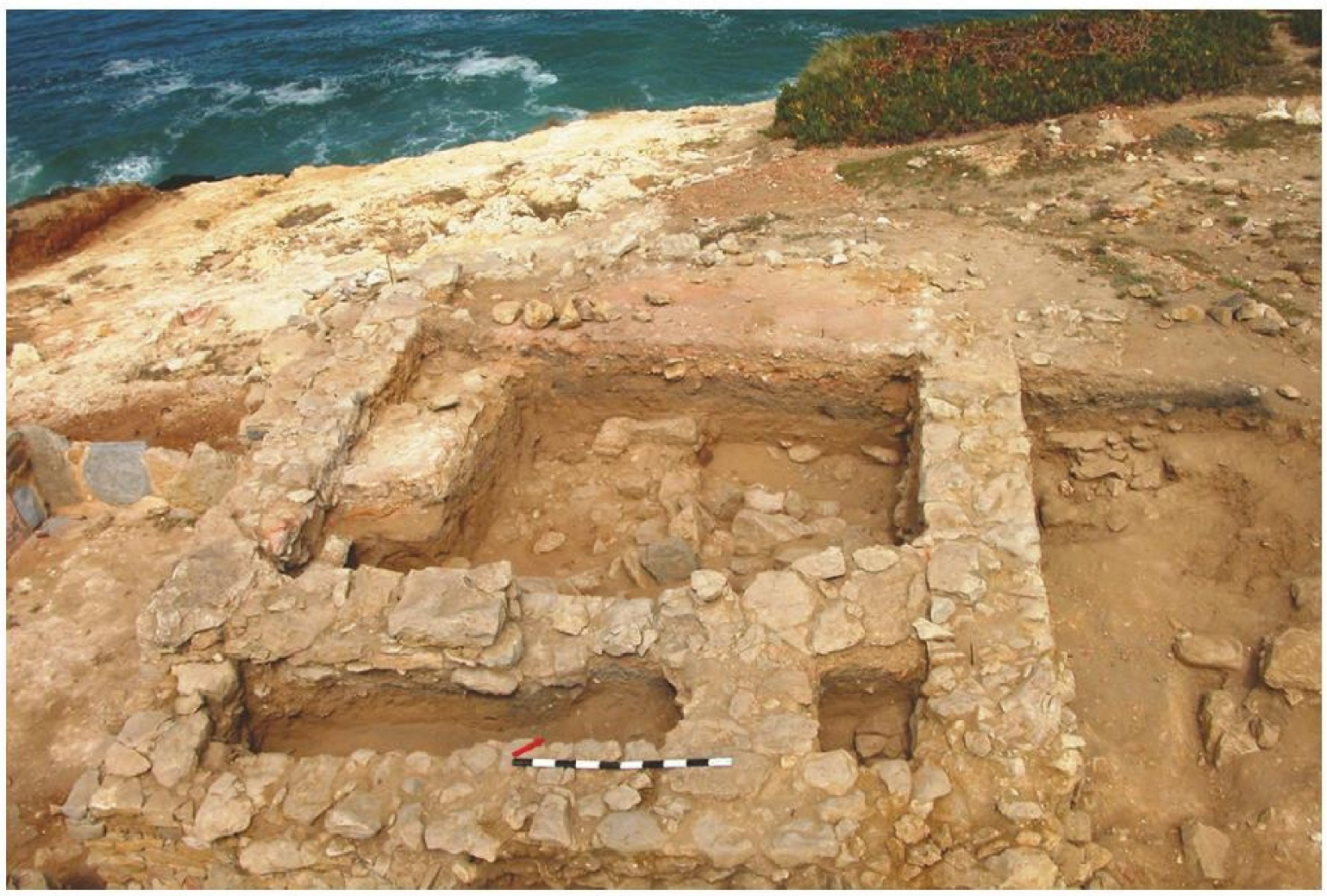

Figura 3 - Aspeto da vigia da Foz de Colares durante os trabalhos. O corte ná área de éscavação ilustra a sequência éstratigráfica daquele edificio. 


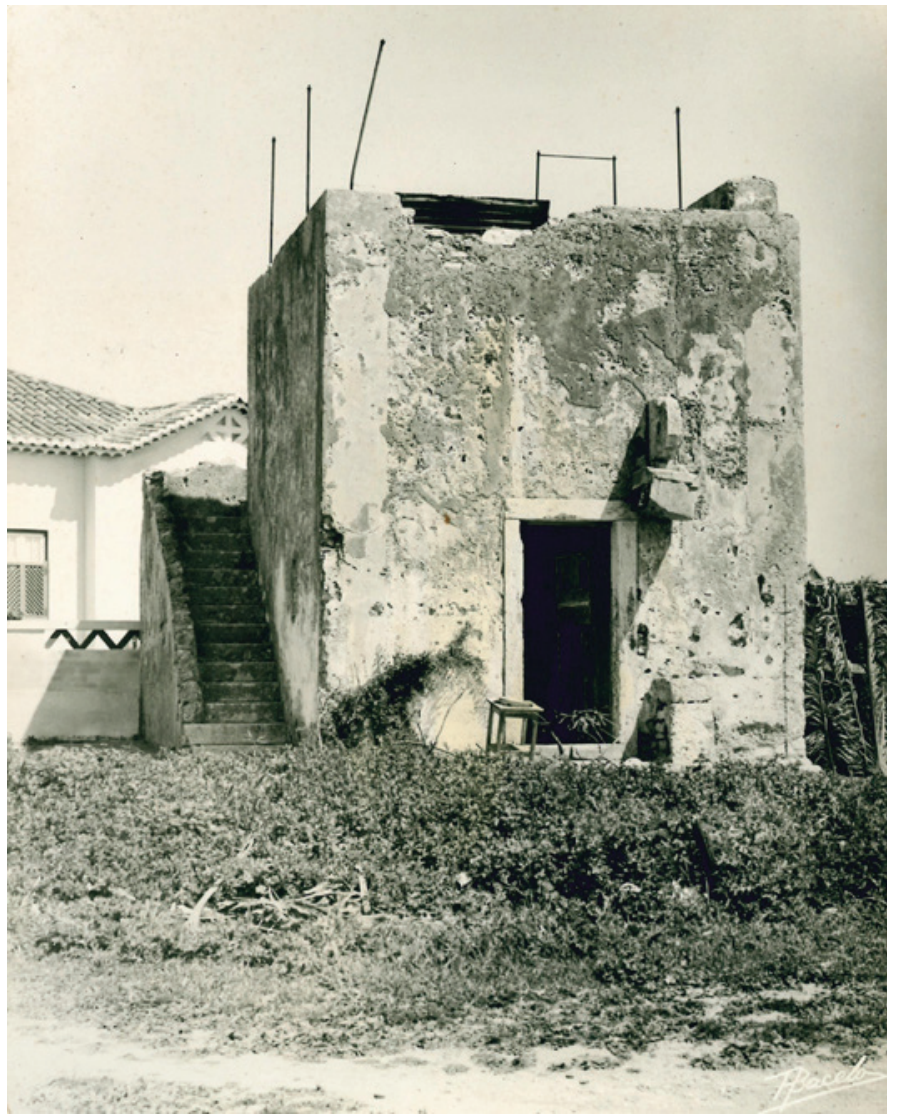

Figura 4 - Fachada Sul da vigia da Parede, em Cascais.

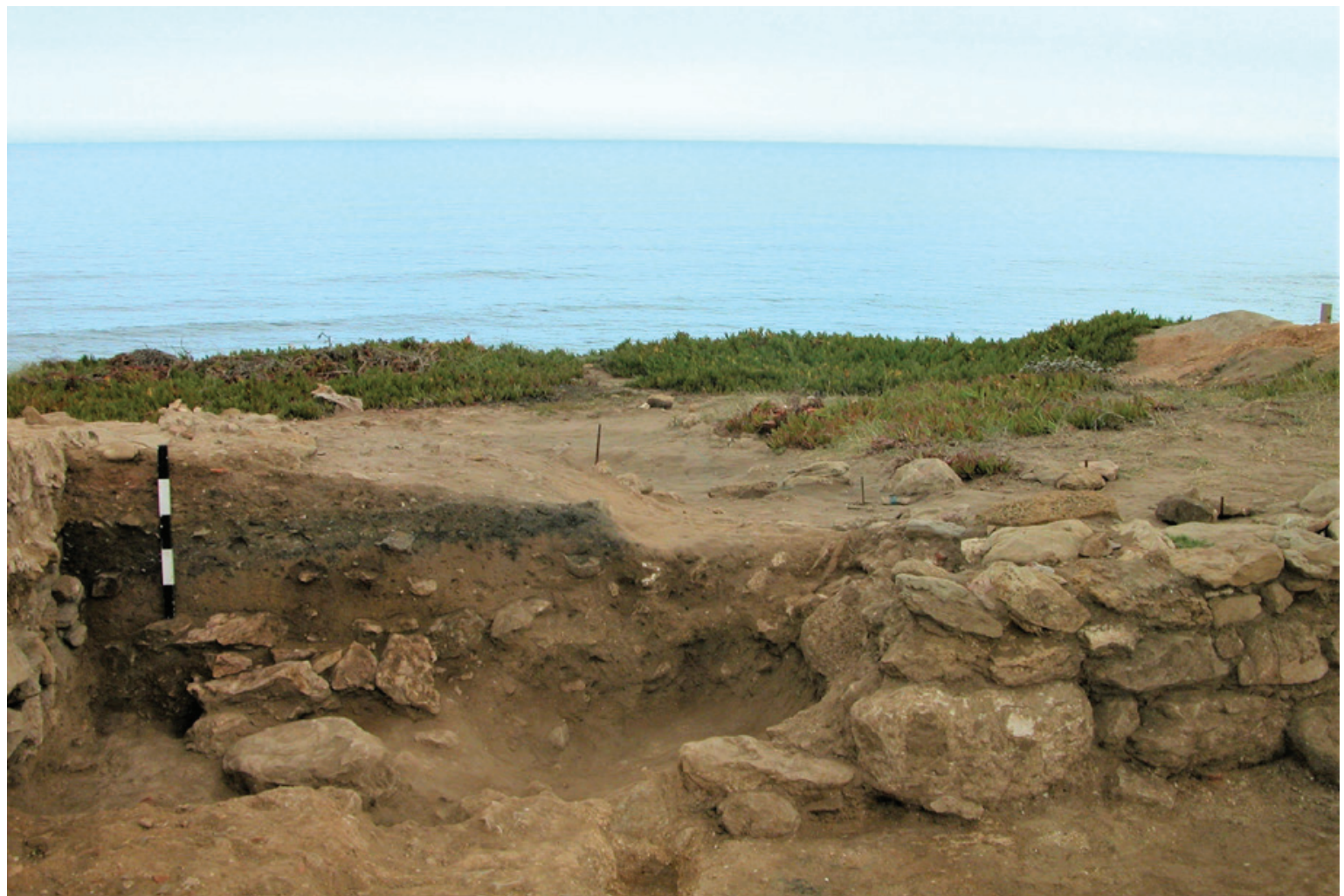

Figura 5 - Pormenor de corte da vala dos alicerces da vigia, com fragmentos de peças lapidares romanas misturados com areia. À direita é visível uma parede islâmica parcialmente desmontada. 


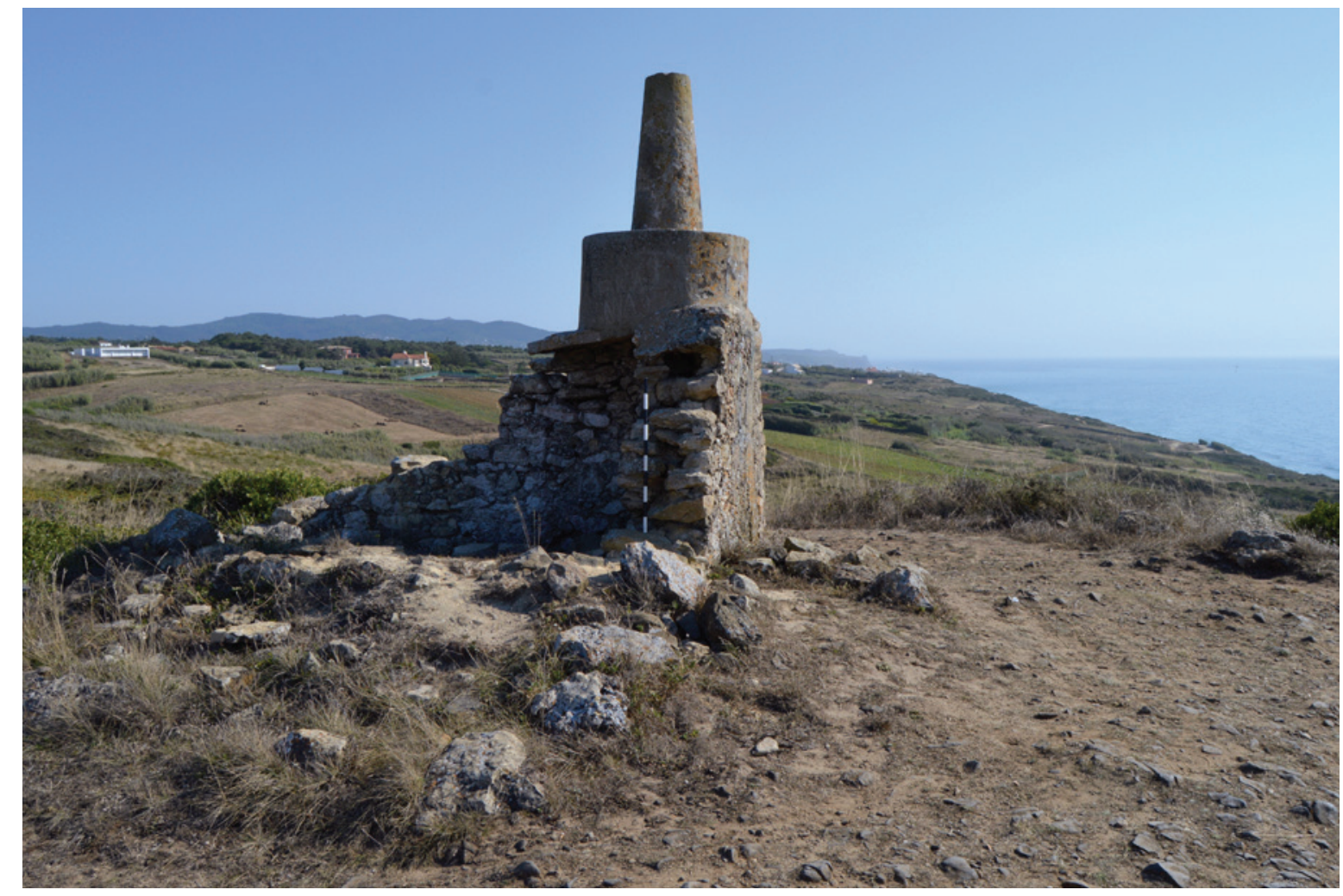

Figura 6 - Prováveis ruínas da vigia da Mata ou do Magoito.

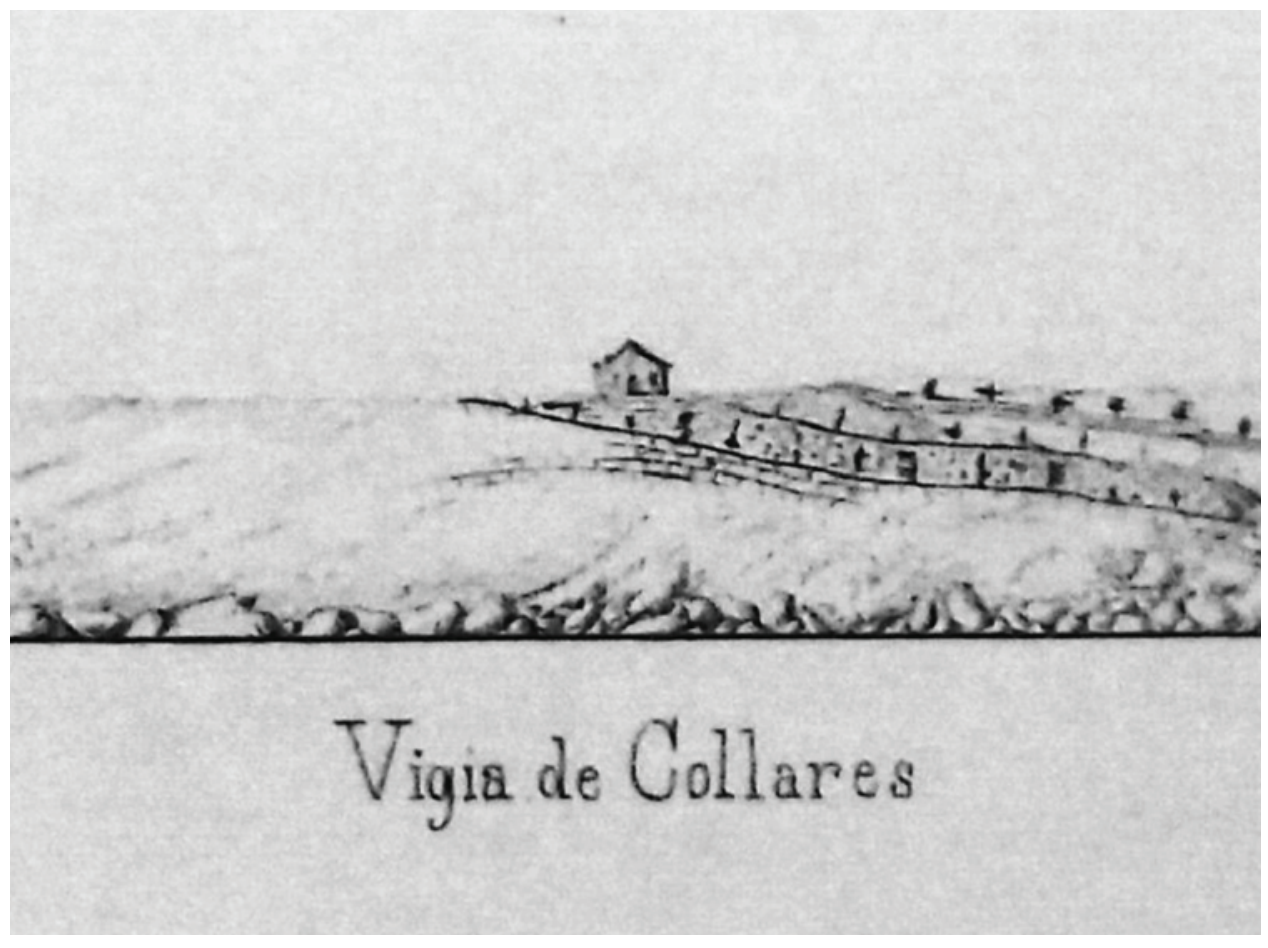

Figura 7 - Representação da "Vigia de Collares" feita por Carlos Ribeiro no início da segunda metade do século XIX. 

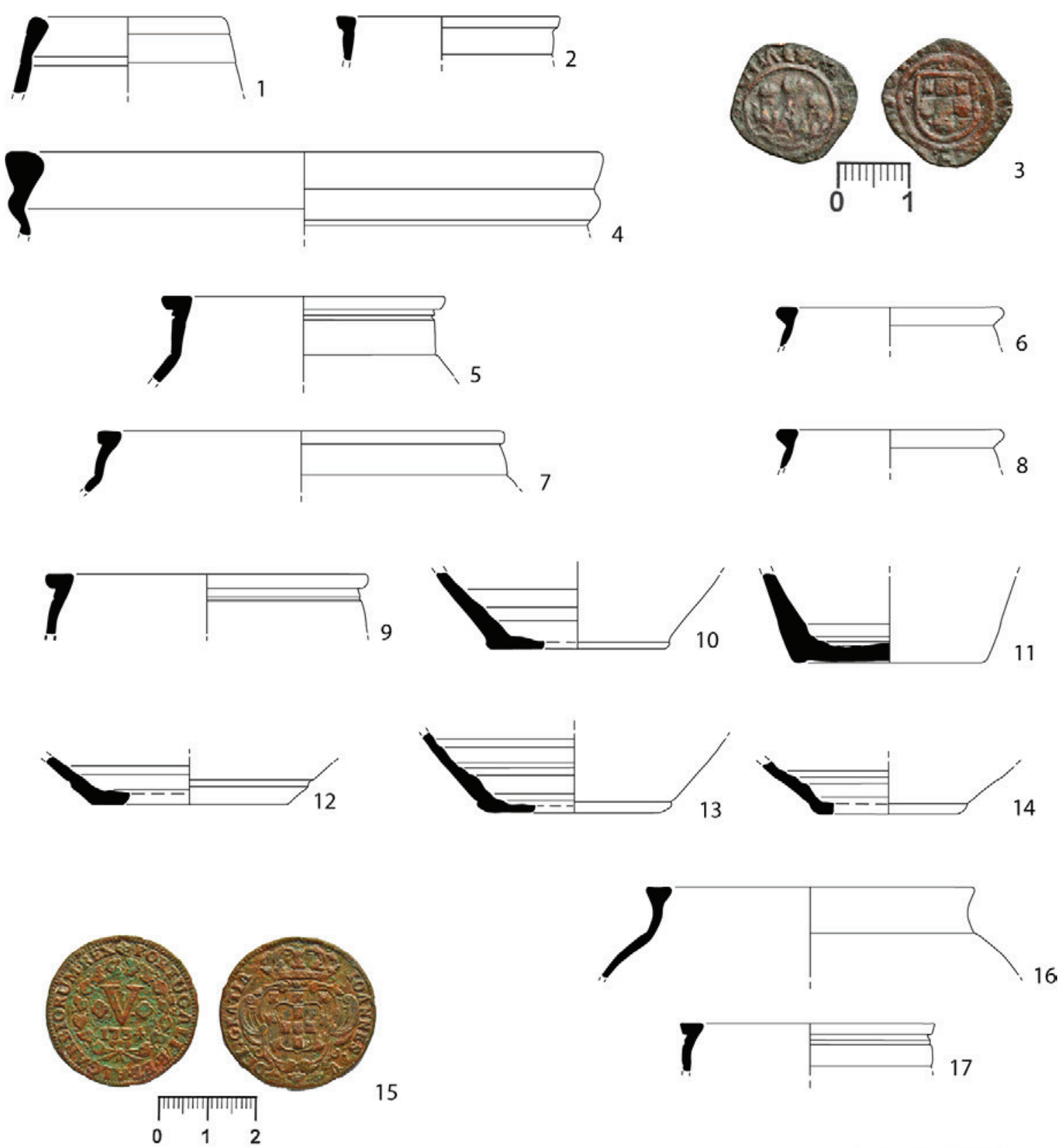

15
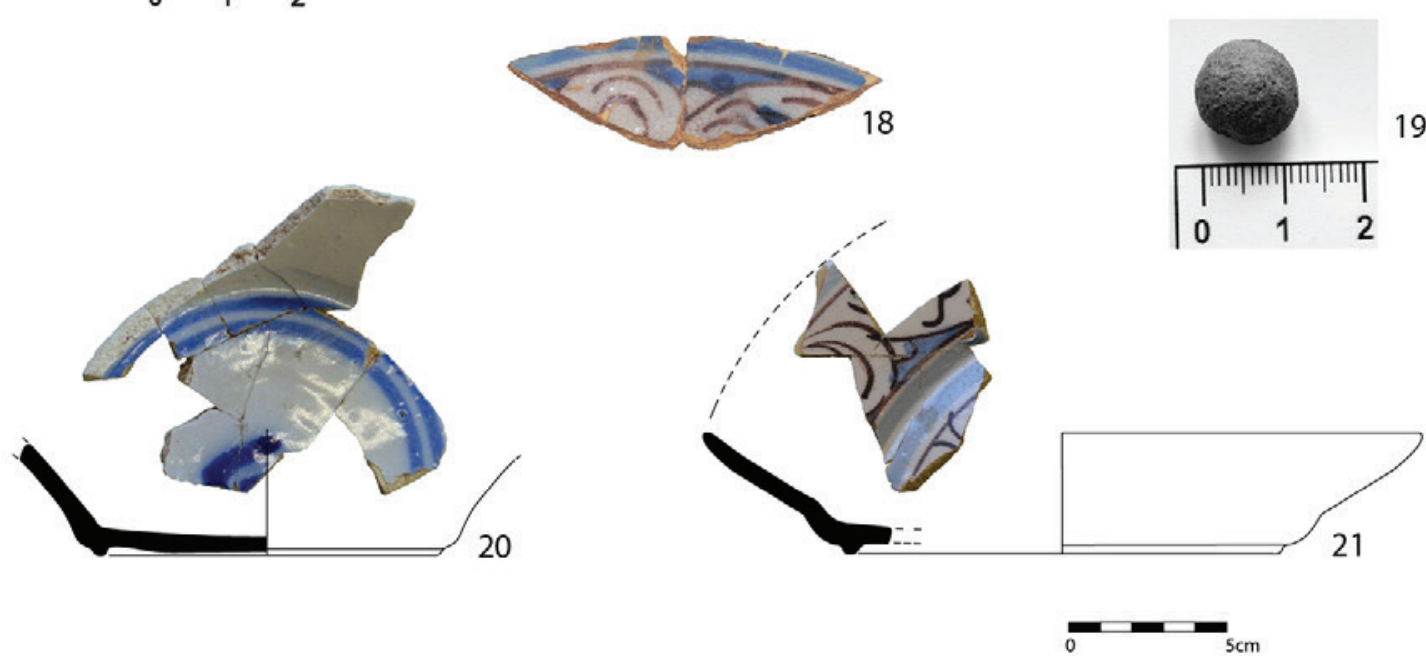

Figura 8 - Materiais associados às ocupações da Vigia: século XVI a XIX. Autor: Ana Isabel. 



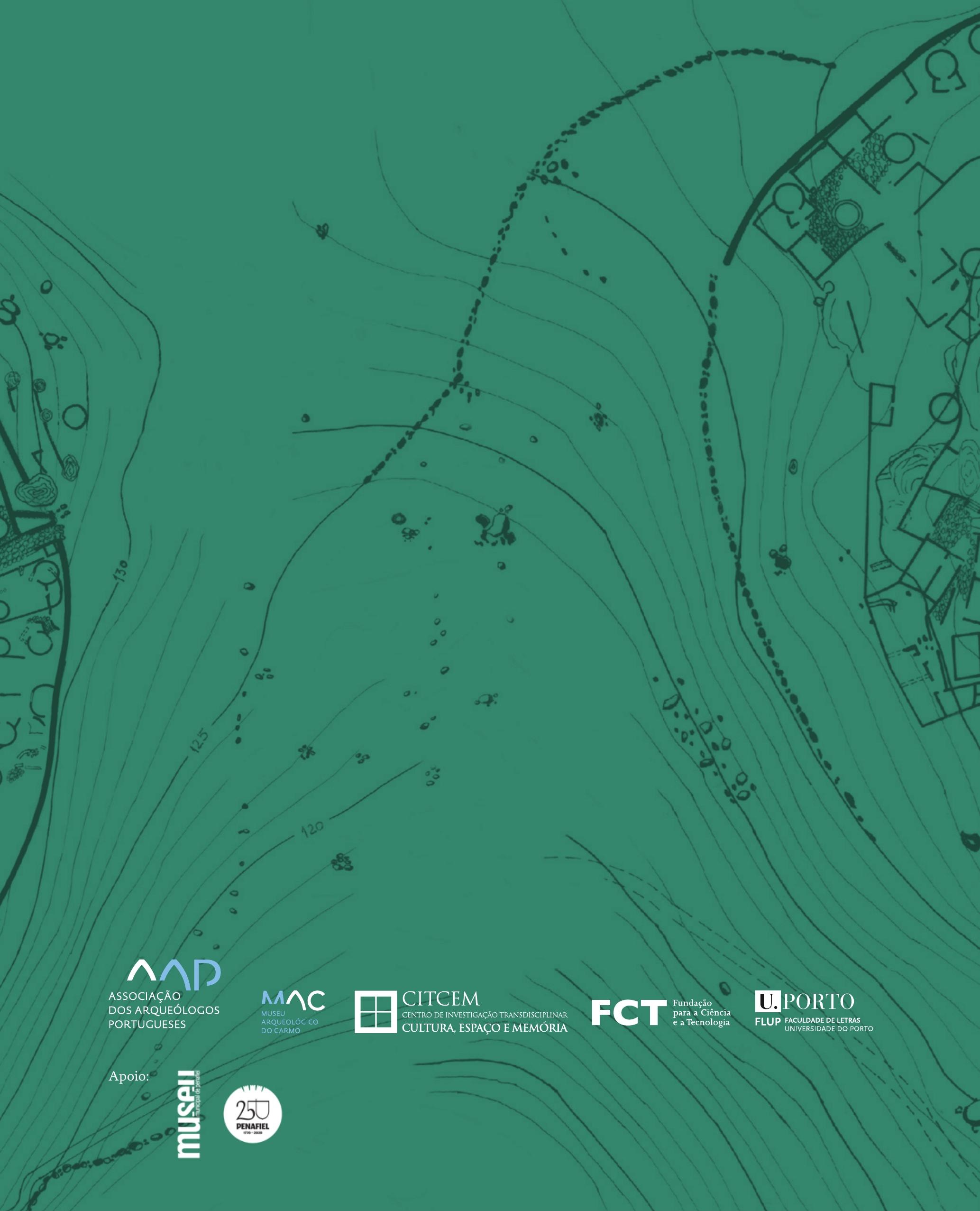

